\title{
Werkloosheidsindicatoren voor schoolverlaters
}

\author{
Citation for published version (APA):
}

Beekman, T. B. J., \& de Grip, A. (1991). Werkloosheidsindicatoren voor schoolverlaters.

Researchcentrum voor Onderwijs en Arbeidsmarkt, Faculteit der Economische Wetenschappen. ROA Research Memoranda No. 1 https://doi.org/10.26481/umaror.1991001

Document status and date:

Published: 01/01/1991

DOI:

10.26481/umaror.1991001

Document Version:

Publisher's PDF, also known as Version of record

\section{Please check the document version of this publication:}

- A submitted manuscript is the version of the article upon submission and before peer-review. There can be important differences between the submitted version and the official published version of record.

People interested in the research are advised to contact the author for the final version of the publication, or visit the DOI to the publisher's website.

- The final author version and the galley proof are versions of the publication after peer review.

- The final published version features the final layout of the paper including the volume, issue and page numbers.

Link to publication

\footnotetext{
General rights rights.

- You may freely distribute the URL identifying the publication in the public portal. please follow below link for the End User Agreement:

www.umlib.nl/taverne-license

Take down policy

If you believe that this document breaches copyright please contact us at:

repository@maastrichtuniversity.nl

providing details and we will investigate your claim.
}

Copyright and moral rights for the publications made accessible in the public portal are retained by the authors and/or other copyright owners and it is a condition of accessing publications that users recognise and abide by the legal requirements associated with these

- Users may download and print one copy of any publication from the public portal for the purpose of private study or research.

- You may not further distribute the material or use it for any profit-making activity or commercial gain

If the publication is distributed under the terms of Article $25 \mathrm{fa}$ of the Dutch Copyright Act, indicated by the "Taverne" license above, 


\section{WERKLOOSHEIDSINDICATOREN VOOR SCHOOLVERLATERS}

ROA-RM-1991/1

Th.B.J. Beekman en A. de Grip

\section{RESEARCHCENTRUM VOOR ONDERWIJS EN ARBEIDSMARKT}

Faculteit der Economische Wetenschappen

Rijksuniversiteit Limburg

Maastricht, maart 1991 


\section{CIP-GEGEVENS KONINKLIJKE BIBLIOTHEEK, DEN HAAG}

Beekman, Th.B.J.

Werkloosheidsindicatoren voor schoolverlaters/Th.B.J. Beekman en A. de Grip.- Maastricht: Researchcentrum voor Onderwijs en Arbeidsmarkt, Faculteit der Economische Wetenschappen, Rijksuniversiteit Limburg. - (Rapport / Researchcentrum voor Onderwijs en Arbeidsmarkt, ISSN 0922-8098; 1991/1)

Met lit. opg.

ISBN 90-5321-053-9 in spiraalband

Trefw.: werkloosheid / schoolverlaters 


\section{INHOUDSOPGAVE}

Bladzijde

1. INLEIDING

2. OVERZICHT VAN MOGELIJKE MODELLEN

3. BESCHRIJVING VAN DE BESCHIKBARE DATA 6

4. WERKLOOSHEIDSINDICATOREN 10

5. DE REGIONALE WERKLOOSHEIDSINDICATOR 15

6. CONCLUSIES 17

LITERATUUR

BIJLAGEN:

I : OVERZICHT VAN DE OPLEIDINGSTYPEN 19

II : SCHATTINGSRESULTATEN VAN MEESTERS EN HUSON (1990) 21

III : NIET-PARAMETRISCHE SCHATTING VAN DE SURVIVAL-CURVE 22

IV : ARBEIDSMARKTINDICATOR VAN ROA-OPLEIDINGSCATEGORIEËN 23

V : OVERZICHT VAN DE DATASET EN SCHATTINGSRESULTATEN

VI : SCHATTINGSRESULTATEN VAN HET COX MODEL 26

VII : DE INDELING VAN DE RBA-REGIO'S 28

VIII: LANDELIJK WERKLOOSHEIDSPERCENTAGE PER OPLEIDINGSTYPE 29

IX : DE WERKLOOSHEIDSINDICATOR NAAR OPLEIDINGSTYPE PER RBA-REGIO, 30 APRIL 1990

$X \quad:$ KENGETALLEN NAAR OPLEIDINGSTYPE PER RBA-REGIO, APRIL 1990 


\section{INLEIDING}

In opdracht van het Ministerie van Onderwijs en Wetenschappen werkt het Researchcentrum voor Onderwijs en Arbeidsmarkt (ROA) aan de ontwikkeling van een informatiesysteem onderwijs-arbeidsmarkt ten behoeve van de studie- en beroepskeuzevoorlichting aan leerlingen en studenten in het voortgezet en hoger onderwijs. Tevens kan dit informatiesysteem van nut zijn voor de capaciteitsplanning van de onderwijsvoorzieningen en het recruteringsbeleid van zowel het bedrijfsleven als overheidsinstanties.

Prognoses van de arbeidsmarktperspectieven van beroepen en opleidingen vormen in feite het belangrijkste onderdeel van het informatiesysteem. Daarnaast bestaat er echter, zowel binnen het werkveld van de studie- en beroepskeuzevoorlichting, als bij het recruteringsbeleid van arbeidsorganisaties, eveneens een behoefte aan 'arbeidsmarktindicatoren'. Bij de studie- en beroepskeuzevoorlichting zijn prognoses immers vooral bedoeld om de kans op het vinden van een eerste baan na het afronden van een opleiding aan te geven. Het is echter ook belangrijk om een indicatie te hebben van de risico's die men daarbij loopt.

In deze studie staat centraal het construeren van een arbeidsmarktindicator ten aanzien van de actuele situatie op de arbeidsmarkt, met name met betrekking tot het risico voor schoolverlaters om een bepaalde periode na het schoolverlaten werkloos te zijn. Met andere woorden de studie heeft als doel het bepalen van een indicator voor de actuele werkloosheid van schoolverlaters naar opleidingstype. De indicator zal moeten aangeven in hoeverre een werkzoekende schoolverlater van een bepaald opleidingstype rekening moet houden met een bepaalde periode van werkloosheid. Daarbij is niet alleen de kans om werkloos te worden van belang, maar ook de lengte van een dergelijke periode.

De aldus geconstrueerde werkloosheidsindicator voor schoolverlaters zou onderdeel kunnen gaan uitmaken van het ROA-informatiesysteem onderwijs-arbeidsmarkt en zou ook kunnen worden toegepast in het I-See! informatiesysteem voor beroep- en opleidingskeuze (zie Dekker c.s. 1990). Op dit moment bevat het informatiesysteem alleen het werkloosheidspercentage op nationaal niveau van de circa 50 door het ROA op basis van het 3-digitniveau van de Standaard Onderwijs Indeling (SOI) van het CBS onderscheiden opleidingstypen ${ }^{1}$. Tevens wordt een indicatie gegeven van het aandeel van schoolverlaters in de totale werkloosheid van een bepaald opleidingstype. Het is de bedoeling dat deze maatstaven zo mogelijk worden vervangen

1. Zie Bijlage I voor een overzicht van de onderscheiden opleidingstypen. 
door een indicator die verder is uitgesplitst naar (RBA ${ }^{2}$-)regio en/of naar opleidingstype op een lager aggregatieniveau; bij voorkeur SOI 5-digit.

Voor deze studie is gebruik gemaakt van de bestanden van de geregistreerde werkzoekenden van de arbeidsbureaus. Bij het gebruik van deze bestanden moet rekening worden gehouden met de vervuiling die optreedt bij deze werkloosheidsmeting (zie Detmar en Dekker, 1987). Bovendien treedt bij een dergelijke data-set het verschijnsel 'length biased sampling' op, omdat het databestand niet bestaat uit een willekeurige groep werklozen die allemaal op hetzelfde moment werkloos zijn geworden. Het gebruik van een bestand op een bepaald moment heeft tot gevolg dat er een grotere kans is op lange werkloosheidsduren dan op korte duren. Dit heeft vanzelfsprekend ook gevolgen voor de representativiteit van het bestand.

De verdere opzet van deze studie is als volgt. Eerst wordt in hoofdstuk 2 nader ingegaan op enkele mogelijk bruikbare onderzoeksmodellen om te komen tot een meer adequate indicator van de actuele arbeidsmarktsituatie naar opleidingstype en worden enkele eerdere onderzoeken naar de werkloosheidsduur van schoolverlaters besproken. In paragraaf 3 wordt vervolgens het databestand beschreven, waarna in paragraaf 4 een eenvoudige werkloosheidsindicator wordt bepaald en een eenvoudig duurmodel wordt geschat. Ook worden de resultaten besproken van de schattingen van een verklarend model van de werkloosheidsduur van schoolverlaters en de implicaties. Hoofdstuk 5 gaat in op de mogelijkheid om te komen tot een geregionaliseerde werkloosheidsindicator voor schoolverlaters. Tenslotte worden in paragraaf 6 enkele conclusies getrokken over de bruikbaarheid van de verschillende besproken maatstaven en methoden van aanpak.

2. Regionaal Bestuur voor de Arbeidsvoorziening. 


\section{OVERZICHT VAN MOGELIJKE MODELLEN}

De afgelopen jaren zijn er ook in ons land een aantal studies verricht waarin is geprobeerd een schatting te maken van de werkloosheidsduren van schoolverlaters. In dit hoofdstuk worden enkele verschillende mogelijke onderzoekmodellen besproken, voor zover mogelijk met een voorbeeld van een empirisch onderzoek waarin een dergelijk model werd toegepast.

Een eerste mogelijkheid is het bepalen van een eenvoudige statistische maat waarin de grootte en de verdeling van de werkloosheidsduur van de huidige populatie werkzoekende schoolverlaters met een bepaalde opleidingscode ${ }^{3}$ worden samengenomen. Een voordeel is de eenvoudige wijze waarop deze maat kan worden bepaald. Een voorbeeld van een dergelijke maat is de arbeidsmarktindicator van Van Paridon (1987). Deze arbeidsmarktindicator relateert het voor vervuiling gecorrigeerde aantal werkloze schoolverlaters dat korter dan een jaar staat ingeschreven aan het totaal aantal schoolverlaters in het voorafgaande jaar. Voor de opleidingen in het wetenschappelijk onderwijs zou daarbij eigenlijk een andere maximale werkloosheidsduur dan de periode van een jaar moeten worden gekozen, omdat afgestudeerden van deze opleidingen niet op een vast tijdstip aan het einde van het studiejaar uitstromen uit het onderwijs.

Een tweede mogelijkheid is het schatten van een verklarend duurmodel. Een verklarend duurmodel is een model waarin waargenomen werkloosheidsduren worden verklaard aan de hand van persoonlijke kenmerken van individuen en omgevingskenmerken (zoals de lokale arbeidsmarkt). Er wordt daarbij verondersteld dat deze kenmerken een verschuiving ten opzichte van een basisverdeling (de 'base-line') van de werkloosheidsduur bewerkstelligen. Daarbij dient men a priori een expliciete keuze te maken over de vorm van deze basisverdeling. Uit deze schatting kunnen de conditionele uittredekansen voor de verschillende opleidingscategorieën worden bepaald. Deze conditionele kansen kunnen dan worden gebruikt als basis voor de verwachte werkloosheidsduur per opleidingscategorie voor werkloze schoolverlaters.

Een recent voorbeeld van deze aanpak is de studie van Kerckhoffs en De Neubourg (1990), op basis van de geregistreerde werkloosheidsdata.

Bij het gebruik van een dergelijk model is het noodzakelijk dat er voldoende verklarende variabelen worden opgenomen, vanwege mogelijke 'unobserved heterogeneity' (zie Lancaster

3. De opleiding van de werkzoekende is door de arbeidsbureaus gecodeerd volgens de zogenaamde AROI-codering. Deze codering is door ons vertaald naar de equivalente SOIcode. Deze laatste kan weer worden omgezet naar de 50 in het ROA-informatiesysteem onderkende opleidingstypen. 
1979), of dat deze niet-geobserveerde heterogeniteit expliciet wordt gemodelleerd (zoals door Kerckhoffs en De Neubourg wordt gedaan). Niet-geobserveerde heterogeniteit betekent dat het gedeelte van de steekproef dat na verloop van tijd overblijft in de werklozenbestanden een geringere uitstroomkans heeft vanwege een niet-waargenomen kenmerk. Indien dit kenmerk niet is opgenomen als exogene, zal het effect - ten onrechte - worden toegeschreven aan andere exogenen of aan het verloop in de tijd van de basisverdeling. Verwaarlozing van dit verschijnsel kan derhalve leiden tot onjuiste waarden voor de parameters, maar vooral tot een verkeerde inschatting van de tijdsafhankelijkheid van de conditionele uittredekans (uit de werkloosheid). Het lijkt dan als of personen die langer werkloos zijn ceteris paribus een steeds kleinere conditionele kans hebben om uit de werkloosheid te ontsnappen, terwijl dit in feite is toe te schrijven aan een niet waargenomen persoonlijk kenmerk.

Een ander recent voorbeeld van een studie waarin deze aanpak is gevolgd, is het onderzoek van Van Opstal en Van de Pol (1990) naar de werkloosheidsduur van schoolverlaters. In deze studie is getracht de tijdsafhankelijkheid van de 'hazard' ${ }^{4}$ te modelleren. Daarbij worden verschillende specificaties voor de basisverdeling van de hazard gebruikt en de niet-waargenomen heterogeniteit wordt expliciet gemodelleerd. Er kan op basis van dit onderzoek echter geen eenduidige conclusie worden getrokken welke basisverdeling de beste beschrijving van de data geeft.

Een derde mogelijke aanpak is het schatten van de verwachte werkloosheidsduur voor schoolverlaters met behulp van een semi-parametrische schattingsmethode. Een semiparametrische schattingsmethode betekent dat er geen expliciete keuze wordt gemaakt voor de basisverdeling van de hazard, maar wel voor de invloed van de exogenen op de basisverdeling. Dit model wordt geschat op basis van een partiële likelihood, namelijk de likelihood ten opzichte van een niet nader gespecificeerde baseline hazard. Het is op eenvoudige wijze mogelijk de hazards van de verschillende opleidingscategorieën te schatten met behulp van het 'proportional hazards'-model (Cox en Oakes 1984). Daarvoor is het wel noodzakelijk dat de populatie in homogene subgroepen wordt ingedeeld. Net als bij het tweede model kunnen ook hier de conditionele uittredekansen voor de verschillende opleidingscategorieën worden bepaald. Deze conditionele kansen vormen dan de basis voor de verwachte werkloosheidsduur per opleidingscategorie voor werkloze schoolverlaters.

4. De 'hazard' is de conditionele uittredingskans; dit is de kans dat, gegeven het feit dat het individu tot tijdstip $t$ werkloos is geweest, het individu in de komende periode $(t+d t)$ uit het werklozenbestand zal uitstromen (de term 'hazard' verwijst naar de oorspronkelijke formulering van de theorie, waar het gaat om de kans dat, gegeven het feit dat een patiënt tot tijdstip $t$ in leven is gebleven, de patiënt in de periode $t+d t$ zal overlijden). 
Een voorbeeld van een dergelijk proportional hazards-model is de studie van Meesters en Huson (1990). Zij schatten een verklarend model voor de startwerkloosheid van schoolverlaters op basis van de CBS-dataset met gegevens van schoolverlaters uit de periode 1977-1987, die ruime informatie over de achtergrondkenmerken van de schoolverlaters bevat. Meesters en Huson groeperen deze data per schooltype zodat er per groep ruim voldoende waarnemingen zijn om een uitgebreid model te specificeren. Ook splitsen ze de analyse op in een logit-analyse, waarin wordt bepaald welke schoolverlaters direct een baan vinden (zie tabel II.1 van bijlage II), en een duur-analyse, waarin de duur van de startwerkloosheid wordt verklaard aan de hand van een aantal achtergrondkenmerken: opleiding en geslacht (zie tabel II.2 van bijlage II). Voor de duur-analyse wordt het proportional hazards model van Cox (zie Kalbfleisch en Prentice 1980) gebruikt. Dit model kan worden geschat op basis van de partiële likelihood, zodat er geen baseline-hazard hoeft te worden gespecificeerd. Zoals reeds blijkt uit de beide tabellen van Bijlage II wordt in het onderzoek van Meesters en Huson slechts in beperkte mate gedesaggregeerd naar opleiding. In totaal wordt naast de ongediplomeerden, slechts een vijftal schooltypen, zonder enige verdere specifering, onderscheiden: LBO, MAVO, HAVO, VWO en MBO. 


\section{BESCHRIJVING VAN DE BESCHIKBARE DATA}

In dit hoofdstuk wordt ingegaan op de belangrijkste gegevensbronnen die in deze studie worden gebruikt. Allereerst wordt het geregistreerde werkzoekendenbestand beschreven en wordt ingegaan op de vervuiling van dit bestand. Daarna wordt het gebruikte schoolverlatersbestand behandeld.

Het databestand dat in deze studie wordt gebruikt is afkomstig uit het ISVA-bestand (Informatie Systeem Vraag en Aanbod). Het ISVA-bestand bevat de gegevens die de afzonderlijke arbeidsbureaus hebben geregistreerd van de bij hen ingeschreven werkzoekenden (verderop ook aangeduid met 'ingeschrevenen'). Uit het ISVA-bestand zijn door ons de werkzoekenden geselecteerd die voldoen aan de volgende kenmerken:

- jonger dan 65 jaar;

- zonder werk;

- bereid en in staat 20 uur of meer per week te werken.

Dit zijn de eisen die moeten worden opgelegd om de omvang van het zogenaamde 'Bemiddelingsbestand Zonder Baan (BZB)' te bepalen. Dit bestand vormde tot voor enkele jaren de basis voor de berekening van het officiële werkloosheidscijfer. Vervolgens zijn hieruit de werklozen geselecteerd die ingeschreven staan als schoolverlater. Het resulterende gegevensbestand bevat enerzijds de gegevens op een bepaald moment (17 april 1990) van alle op dit tijdstip ingeschreven werkloze schoolverlaters en anderzijds voor een bepaalde periode (de maand april 1990) de gegevens van alle schoolverlaters die zich uit het ISVA-bestand hebben laten uitschrijven.

Van elke ingeschrevene is bekend op welk tijdstip hij of zij is ingestroomd in het bestand van werklozen. Het is echter niet bekend op welk moment deze personen weer zullen uitstromen naar de arbeidsmarkt (of naar een andere bestemming). De bij deze personen waargenomen werkloosheidsduur wordt daarom een onvoltooide werkloosheidsduur genoemd. Bij dergelijke onvoltooide duren is niet bekend wat de uiteindelijke werkloosheidsduur voor de desbetreffende persoon zal zijn, maar wel dat deze groter zal zijn dan de tot nu toe waargenomen duur. Bij voltooide duren is daarentegen wel de totale werkloosheidsduur bekend. Hieruit blijkt al dat voltooide duren meer informatie geven over de gemiddelde werkloosheidsduur dan onvoltooide duren.

Er zijn diverse mogelijkheden om de gegevens uit bovengenoemde bestanden te combineren tot een maatstaf voor de gemiddelde werkloosheidsduur voor schoolverlaters. Een eerste mogelijkheid is het bepalen van de gemiddelde werkloosheidsduur van schoolverlaters met 
behulp van de gegevens over de totale instroom van schoolverlaters op de arbeidsmarkt op een bepaald tijdstip. Op basis van de werklozenbestanden kan dan voor deze groep schoolverlaters de werkloosheidsduur worden bepaald. Dit geeft enige informatie over het verloop van de uittredekans van schoolverlaters. De problemen die zich hierbij voordoen zijn het ontbreken van informatie over de schoolverlaters die nooit in het werklozenbestand zijn terecht gekomen, de verdeling van de werkloosheidsduren van schoolverlaters die tussentijds het bestand verlaten en de verdeling van de voltooiing van de duren van de op het metingsmoment nog werkloze schoolverlaters.

Een tweede manier is het koppelen van bovenstaand onderzoeksbestand met een meting op een ander tijdstip. Dat deel van de werklozen dat wel op het eerste en niet op het tweede tijdstip wordt gemeten geeft enige informatie over de uittredekansen van deze groep in de tussenliggende periode. Ook hier doet zich het probleem voor dat de verdeling van de duren van de groep die in de tussenliggende periode uittreedt niet bekend is. Bovendien is de voltooiing van de werkloosheidsduur van degenen die op het tweede tijdstip nog werkloos zijn niet bekend.

Een derde manier van aanpak is alleen gebruik te maken van de gegevens van degenen die in een bepaalde periode werden uitgeschreven. Op deze wijze kunnen wel voltooide duren worden geconstrueerd. Deze groep uitschrijvers is echter geen aselecte steekproef uit de populatie van de werkloze schoolverlaters: waarschijnlijk zijn de meest kansrijken, die de kortste werkloosheidsduur zullen hebben, oververtegenwoordigd.

Een vierde manier is het combineren van een bepaalde momentopname van de werkloosheid van schoolverlaters, met de omvang van de uitstroom uit de werkloosheid in de desbetreffende maand. Op deze wijze kan het gehele bestand worden beschreven en ook worden beschikt over voldoende voltooide duren. Op deze laatste wijze zal ons onderzoeksbestand worden samengesteld, omdat op deze manier over de meest uitgebreide informatie wordt beschikt.

De gegevens over het totaal aantal schoolverlaters in het voorafgaande jaar kunnen worden geconstrueerd met behulp van gegevens uit verschillende bestanden, zoals bijvoorbeeld de Integrale LeerlingenTellingen, de RUBS-enquête en de onderwijsmatrices van het CBS, zoals ook in het kader van het RUVO-project ${ }^{5}$ is gedaan (Vermeulen, 1990). De resultaten van dit RUVOonderzoek betreffen het aantal gediplomeerde schoolverlaters, dat geen voltijdsonderwijs meer volgt, naar RBA-regio.

5. Regionalisering uitstroom Voortgezet Onderwijs (RUVO). 
Op basis van enquête-onderzoeken is gebleken dat de werkzoekenden-bestanden van de arbeidsbureaus ernstig zijn vervuild (zie bv. Dekker, Detmar en Van Hoesel, 1986). Herhaling van de enquête naar de vervuiling van het geregistreerde werklozenbestand in 1986 en 1987 leverde een soortgelijk beeld op. Deze vervuiling houdt in dat een deel van de als werkloos ingeschrevenen in werkelijkheid niet aan alle eisen voldoet, om (officieel) als werkloze te worden beschouwd. De vervuiling treedt op als men:

- op het moment van meting toch betaald werk (incl. uitzendwerk en freelance) verricht;

- niet beschikbaar is (vanwege studie of gezondheid) voor de arbeidsmarkt;

- minder dan 20 uur wenst te werken.

In Dekker en Detmar (1987) wordt de vervuiling (door hen bepaald op 40,9\% van de werklozen) uitgesplitst naar enkele achtergrondkenmerken zoals leeftijdsklasse, opleidingsniveau, inschrijvingsduur, beroepsgroep, provincie en grootte van het arbeidsbureau. Uit hun onderzoek blijkt dat de vervuiling duidelijk groter is voor jongeren, hoger opgeleiden en kort ingeschrevenen. Ook zijn er flinke verschillen tussen de diverse beroepsgroepen. De vervuiling is overigens - na correctie voor seizoensinvloeden - wel enigszins teruggelopen vergeleken bij 1986, wegens de invoering van een kortere herinschrijvingstermijn. Ook is in dit onderzoek een schatting van de 'omgekeerde vervuiling' gemaakt. Uit enquêtegegevens blijkt $25,8 \%$ van de niet als werkloos aangemerkte ingeschrevenen in de praktijk wel degelijk aan alle criteria van de formele werkloosheidsdefinitie te voldoen. Het resultaat van bovengenoemde over- en onderschattingen van de omvang van de werkloosheid is een netto vervuiling van $33,6 \%$.

Overigens wordt door Dekker en Detmar opgemerkt dat bij een iets ruimere definitie van werkloosheid, die beter aansluit bij de bemiddelingsdoeleinden van de arbeidsbureaus, de vervuiling slechts $14,3 \%$ bedraagt. Deze alternatieve werkloosheidsdefinitie wijkt af van de huidige definitie doordat de alternatieve definitie 'alleen werkzoekenden buiten de werkloosheidstelling houdt die (pas) over meer dan een maand beschikbaar zijn danwel (reeds) langer dan drie maanden een baan van meer dan 20 uur per week uitoefenen'.

Op 17 april 1990 staan er in totaal ongeveer 74.000 schoolverlaters ingeschreven bij de arbeidsbureaus. Wanneer we een schoolverlater definiëren als iemand die maximaal een jaar geleden het dagonderwijs heeft verlaten, blijven er nog ongeveer 43.000 personen over. Dit aantal is wel iets hoger dan het aantal genoemd in de 'Schoolverlatersbrief 1990' (Ministerie van Sociale Zaken, 1990), omdat daar een leeftijdsgrens van maximaal 22 jaar is opgelegd.

De bovengenoemde gegevens, het ISVA-bestand en de gegevens verkregen op basis van het RUVO-onderzoek, worden in de hierna volgende hoofdstukken gebruikt om enkele indicatoren 
$-9-$

voor de werkloosheid van schoolverlaters te construeren. Wanneer er indicatoren worden berekend, dan worden er naast de RUVO-gegevens over de aantallen schoolverlaters, alleen gegevens van ingeschrevenen werklozen gebruikt. De gegevens van uitschrijvers uit het werklozenbestand worden toegevoegd als extra informatie bij het gebruik van een duurmodel. 


\section{WERKLOOSHEIDSINDICATOREN}

In dit hoofdstuk worden enkele van de in hoofdstuk 2 genoemde modellen toegepast op het beschikbare databestand. Als eerste aanzet kan zonder enige verdere aanname te maken de survival-verdeling van het databestand worden bepaald. Dit is een grafische weergave van het aantal ingeschreven werkzoekenden in de loop van de tijd, waarbij als startpunt voor alle personen hetzelfde tijdstip wordt genomen. Ook is het mogelijk onder bepaalde aannamen een niet-parametrische schatting te maken van de hazard. In dit geval hoeven dus geen aannames te worden gemaakt over het verloop van de hazard-functie (zie ook Narendranathan en Stewart, 1990). Dit wordt echter verder achterwege gelaten. Vervolgens wordt de in hoofdstuk 2 beschreven eenvoudige statistische maatstaf bepaald, waarin het aantal werkloze schoolverlaters wordt gerelateerd aan het totaal aantal schoolverlaters in het voorafgaande jaar. De genoemde tweede mogelijkheid, het schatten van een volledig structureel duurmodel, wordt in deze studie achterwege gelaten vanwege de vele praktische problemen die hierbij optreden.

Er wordt wel een verklarend duurmodel geschat, maar zonder correctie voor niet-waargenomen heterogeniteit. Dit gebeurt slechts ter oriëntatie op het databestand. Als laatste wordt de derde mogelijkheid, het schatten van een proportional hazards-model, uitgevoerd. Tenslotte wordt nader ingegaan op de gevolgde methoden van aanpak en de onderlinge vergelijkbaarheid van de resultaten van de verschillende methoden van aanpak.

Het databestand kan om te beginnen worden gebruikt om een niet-parametrische (dus zonder enige aanname over de vorm van de verdeling) schatting te maken van de survival-verdeling (zie bijlage III), zodat een beeld kan worden gevormd over de uitstroom uit de werkzoekendenbestanden in de loop van de tijd. De populatie wordt daarbij opgesplitst naar geslacht. Uit een vergelijking van beide figuren blijkt dat de uitstroompatronen van mannen en vrouwen voldoende overeenkomt om beide groepen in de verdere analyse samen te voegen.

De aantallen ingeschreven schoolverlaters kunnen worden gekoppeld aan het totaal aantal schoolverlaters om zo een werkloosheidsindicator te construeren. Een voorbeeld van een dergelijke indicator is de Van Paridon-arbeidsmarktindicator (zie Van Paridon, 1987 en De Grip en Heijke 1988). De resultaten hiervan staan vermeld in bijlage IV. Van Paridon construeerde zijn indicator door de ongeschoonde werkloosheid voor vervuiling te corrigeren op basis van een veronderstelde hoge vervuilingsgraad van $60 \%$ en vervolgens te stellen dat de arbeidsmarkt in evenwicht is bij een (geschoonde) frictiewerkloosheid van $6 \%$. In dat geval heeft de Van Paridon indicator de waarde 100. Deze werkloosheidsindicator kan in principe worden berekend met gegevens op 5-digit SOI-niveau. Hiervoor is het wel noodzakelijk dat er kan worden beschikt over betrouwbare schoolverlaterscijfers op hetzelfde verfijnde niveau. Voor WO- en 
HBO-opleidingen kan daarbij gebruik worden gemaakt van de WORSA- en RHOBOS-prognoses. Bij andere opleidingen moet er een schatting worden gemaakt welk deel van de gediplomeerden naar de arbeidsmarkt zal stromen.

Een nadeel van deze Van Paridon-indicator is het tamelijk willekeurige percentage waarmee de werkloosheid wordt geschoond. Zelfs als de vervuiling wordt uitgesplitst naar leeftijd wordt in de diverse onderzoeken naar vervuiling bij lange na geen percentage van $60 \%$ vervuiling gevonden. Zo vinden Detmar en Dekker (1987) voor jeugdigen een vervuilingsgraad van 46,6 \% in 1986 en $43,3 \%$ in 1987. Derhalve is hier een correctiepercentage van $45 \%$ toegepast. Bovendien kan worden afgevraagd of het percentage werkloze schoolverlaters op zichzelf reeds een goede interpreteerbare indicator van de actuele arbeidsmarktsituatie van schoolverlaters is.

Met de gegevens van het onderzoeksbestand (ingeschreven en uitgeschreven werkloze schoolverlaters in de maand april 1990) is ter oriëntatie een schatting uitgevoerd van de inschrijvingsduur op enkele persoonlijke kenmerken. Hiervoor zijn als base line hazard enkele verschillende verdelingen (zoals de Weibull-, exponentiële, logistische en de gamma-verdeling) gebruikt $^{6}$. De gebruikte exogenen zijn leeftijd, leeftijd in het kwadraat en dummies voor geslacht, (ROA)opleidingstype en nationaliteit.

De schattingsresultaten voor de Gamma-verdeling en enkele kenmerken van de gebruikte dataset worden weergegeven in bijlage $\mathrm{V}$. Er is voor gekozen om de resultaten van de Gammaverdeling te presenteren omdat deze verdeling een aantal andere verdelingen als speciale gevallen omvat ${ }^{7}$. Opmerkelijk is nu dat de parameter van de Gamma-verdeling, die de vorm van de verdeling bepaalt, significant verschillend is van zowel 0 als 1 . Dit betekent dat, wanneer de niet-waargenomen heterogeniteit geen verstorende invloed heeft, de speciale gevallen voor de baseline hazard (de lognormale, de Weibull-verdeling en de exponentiële verdeling) worden verworpen. Dit is opmerkelijk omdat in veel soortgelijke modellen wel a priori voor Weibull- of exponentiële verdeling als baseline wordt gekozen. Overigens werd er in de reeds eerder genoemde studie van Van Opstal en Van de Pol (1990) ook al op gewezen dat de keuze voor de Weibull-verdeling als baseline-verdeling minder gelukkig is.

Uit de resultaten mogen geen verregaande conclusies worden getrokken, zeker niet wat betreft het verloop van de hazard in de tijd, omdat er niet is gecorrigeerd voor niet-geobserveerde

6. Kalbfleisch \& Prentice (1980) bieden een uitstekend overzicht over de verschillende modellen en mogelijke specificaties van de basisverdeling voor de hazard.

7. De Gamma-verdeling is een generalisatie van zowel de Weibull-verdeling (en dus ook de exponentiële verdeling) als de lognormale verdeling. 
heterogeniteit. De resultaten kunnen echter wel enig inzicht in de effecten van de exogenen geven. De leeftijd heeft een positieve samenhang met de werkloosheidsduur; de leeftijd in het kwadraat corrigeert dit weer enigszins door een negatieve coëfficiënt. $\mathrm{Er}$ is derhalve sprake van een niet-lineair positief verband tussen werkloosheidsduur en leeftijd. De verwachte werkloosheidsduur voor mannen is lager dan voor vrouwen. De dummy voor nationaliteit impliceert een hogere werkloosheidsduur voor niet-Nederlanders dan voor Nederlanders. De coëfficiënten voor de verschillende opleidingstypen geven de relatieve lengte van de werkloosheidsduren voor de opleidingstypen aan. Een sterk negatieve coëfficiënt bij een bepaald opleidingstype wijst op een relatief korte werkloosheidsduur. Een positieve coëfficiënt wijst op een langere werkloosheidsduur. De significante positieve coëfficiënt van opleidingstype 1 (Basisonderwijs) wijst op een erg lange werkloosheidsduur, namelijk een duur die $70 \%$ langer is dan de basiswerkloosheidsduur.

De kortste werkloosheidsduren worden gevonden bij de opleidingstypen 51 (Farmacie), 49 (Technische wetenschappen), 40 (Hoger horeca onderwijs) en 53 (Econometrie, bedrijfskunde (ir.)). De coëfficiënt van Farmacie duidt daarbij op een gemiddelde werkloosheidsduur van $30 \%$ van de basisduur. De coëfficiënten zijn niet voor alle opleidingstypen significant. Zoals reeds eerder werd opgemerkt zijn de resultaten echter niet volledig betrouwbaar vanwege mogelijke gevolgen van optredende niet-geobserveerde heterogeniteit.

Met de beschikbare gegevens kan ook een proportional hazards-model, het als derde mogelijkheid genoemde model, worden geschat op basis van de partiële likelihood (zie Kalbfleisch en Prentice 1980; Meesters en Huson 1990) ${ }^{8}$. Helaas bleek dit model, vanwege het grote aantal onderscheiden opleidingstypen, om rekentechnische redenen niet in zijn geheel te kunnen worden geschat. Als ad hoc oplossing is er voor gekozen het bestand alleen op te splitsen naar opleidingsniveau (eerste digit van de SOl-indeling). De schatting is daarbij opgesplitst in drie delen, de lager opgeleiden ( $\mathrm{SOI} 2,3$ ), de middelbaar opgeleiden (SOI 4) en de hoger opgeleiden (SOI 5,6). Dit levert de resultaten van bijlage $\mathrm{VI}$.

De resultaten geven de invloed van de exogenen weer op de hazard. Een positieve coëfficiënt betekent dat de exogene een positieve invloed heeft op de hazard, waardoor de (conditionele) kans om uit de werkloosheid te geraken stijgt. Uit de resultaten blijkt de negatieve invloed van de leeftijd op de hazard (enigszins gecorrigeerd door leeftijd in het kwadraat), een negatief effect van de nationaliteit (de dummy is 1 als het iemand met een andere nationaliteit dan de nederlandse betreft) en een positief effect voor mannen. Het effect van het regionale

8. Dit model is voor alle schoolverlaters geschat met de module $2 \mathrm{~L}$ van het statistisch pakket BMDP. 
werkloosheidspercentage (het gemiddelde werkloosheids-percentage per RBA-regio over 1989) is wel significant voor de laagste opleidings-niveaus maar niet voor de hoogste. Dit is wellicht verklaarbaar uit het feit dat personen met een hoger opleidingsniveau mobieler zijn en dus minder afhankelijk van de lokale arbeidsmarkt.

De resultaten voor de verschillende opleidingscategorieën (weergegeven door de parameter van de dummy) lopen sterk uiteen en zijn ook niet altijd significant verschillend van nul. De schattingsresultaten geven hier de invloed op de hazard weer, in tegenstelling tot bijlage $V$, waar het de invloed op de (log-)werkloosheidsduur betrof. De interpretatie van het (verwachte) teken van de verschillende parameters is dus precies tegenovergesteld in beide schattingen.

De meest duidelijke indicator voor de verwachte werkloosheidsduur van een opleidingscategorie is de exponent van de geschatte coëfficiënt. Dit getal geeft de lengte van de verwachte werkloosheidsduur aan ten opzichte van de referentiecategorie (voor ieder opleidingsniveau de eerstgenoemde opleidingscategorie, zie Bijlage I). Een getal van 2 voor opleiding 34 geeft bijvoorbeeld aan dat de verwachte werkloosheidsduur voor deze opleidingscategorie twee maal zo lang is als de verwachte werkloosheidsduur van opleiding 26 (de referentiecategorie, voor dit opleidingsniveau). Nadrukkelijk moet er daarbij op worden gewezen dat deze getallen niet tussen de verschillende niveaus mogen worden vergeleken, vanwege een (mogelijk) verschillende base-line hazard in de verschillende schattingen.

Wanneer de resultaten voor de verschillende opleidingscategorieën worden vergeleken met het vorige model (bijlage V), dan blijkt er een duidelijke overeenstemming te zijn. Hoewel er alleen opleidingscategorieën binnen een en dezelfde subgroep van dit model (bijlage VI) met elkaar mogen worden vergeleken, komen in alle gevallen in dit model de uitschieters naar boven (met een hoge hazard en dus een korte verwachte werkloosheidsduur) overeen met de uitschieters naar beneden in het model van bijlage $V$. In beide gevallen gaat het om de opleidingstypen met een korte verwachte werkloosheidsduur.

De opleidingstypen in de eerste subgroep worden vergeleken met opleidingstype 1 (Basisonderwijs). De gevonden waarden voor deze opleidingstypen zijn erg hoog, wat er op wijst dat 'ongeschoolden' met alleen Basisonderwijs een lage kans hebben om de toestand van werkloosheid te verlaten. In de tweede subgroep scoren opleidingstypen 17 (Middelbaar Laboratoriumonderwijs) en 23 (Middelbare horeca- en kappersopleiding) relatief goed. In de derde subgroep hebben de opleidingstypen 40 (Hoger horeca onderwijs), 49 (Technische wetenschappen), 51 (Farmacie) en 53 (Econometrie en bedrijfskunde (ir.)) relatief de beste kansen uit het werklozenbestand te stromen. 
Wanneer de resultaten uit het laatstgenoemde model worden vergeleken de waarde van de eenvoudige maatstaf van de werkloosheid van schoolverlaters per opleidingstype (zie bijlage IV), dan blijken de opleidingstypen met een gunstige kans in bijlage VI (typen 40, 49, 51 en 53) ook een lage coëfficiënt te hebben (resp. 51, 55, 33, 26, in bijlage IV). Er zijn echter ook opleidingstypen die een ongunstigere kans hebben dan bovenstaande opleidingstypen, maar toch een lagere waarde van de simpele arbeidsmarktindicator. In die gevallen gaat het blijkbaar om een relatief klein aantal werklozen, dat echter wel kampt met lange werkloosheidsduren. Bijvoorbeeld opleidingstype 1 (Basisonderwijs) heeft een redelijke indicatorwaarde (97), maar personen met deze opleiding hebben een lage kans om uit de toestand van werkloosheid te ontsnappen.

Een groot nadeel van de beide duurmodellen is dat er weliswaar veel aandacht wordt geschonken aan de duur van de werkloosheid, als men eenmaal werkloos is, en de verklarende factoren van deze werkloosheidsduur, maar dat de kans om na schoolverlaten werkloos te worden geheel buiten beschouwing blijft. Daarom wordt in de volgende paragraaf, waarin nadere aandacht wordt besteed aan een indicator met betrekking tot regionale verschillen in de werkloosheid naar opleidingstype, alleen gebruikt gemaakt van de bovengenoemde eenvoudige statistische maatstaf als werkloosheidsindicator, omdat alleen hier een koppeling plaatsvindt aan het totale bestand van schoolverlaters en derhalve de hoogte van deze maatstaf ook wordt beïnvloed door de kans op werkloosheid na schoolverlaten. Bovendien zou het schatten van de beschreven werkloosheidsduurmodellen op regionaal niveau, uitgaande van een enigszins verfijnde opleidingsindeling, op basis van de huidige beschikbare programmatuur onmogelijk zijn. 


\section{DE REGIONALE WERKLOOSHEIDSINDICATOR}

Hoewel de mogelijkheden om de gegevens verder uit te splitsen naar regio beperkt zijn, wordt in deze paragraaf toch een poging gedaan om de reeds eerder beschreven werkloosheidsindicator te construeren op een lager regionaal aggregratieniveau. Daarbij is gekozen voor het RBAniveau. Hiervoor zijn naast de aantallen werklozen ook de aantallen schoolverlaters per RBAgebied naar opleidingscategorie nodig (als noemer). Voor deze aantallen schoolverlaters wordt geput uit data afkomstig van het reeds eerder genoemde Regionalisering Uitstroom Voortgezet Onderwijs (RUVO)project (Vermeulen, 1990). Dit bestand bevat voor een aantal opleidingstypen op lager en middelbaar niveau het aantal gediplomeerden, dat uitstroomt uit het voltijds onderwijs. De opleidingstypen op HBO- en WO-niveau zijn hierin weggelaten, omdat de arbeidsmarkt voor personen met een dergelijk opleidingstype waarschijnlijk meer een landelijk dan een regionaal karakter heeft zoals ook reeds bleek uit de schattingsresultaten van de regiovariabelen in bijlage $\mathrm{VI}$.

De hier geanalyseerde (ROA-)opleidingstypen en het corresponderende landelijk werkloosheidspercentage staan vermeld in bijlage VIII. De gebruikte schoolverlatersgegevens hebben betrekking op de uitstroom uit het onderwijs naar de arbeidsmarkt en/of het deeltijdonderwijs. Daarbij is geprobeerd voor alle schoolverlaters het hoogst behaalde diploma vast te stellen. Echter, de uitstroom zonder diploma uit de HAVOIVWO is door ons samengenomen met de uitstroom uit MAVO met diploma. De resulterende indicatoren (percentages werkloze schoolverlaters) staan vermeld in bijlage IX9. In schema IX.2 staan ook de indicatoren vermeld in de vorm van een kwalitatieve typering van de actuele arbeidsmarktsituatie voor schoolverlaters, uiteenlopend van relatief erg gunstig tot relatief erg ongunstig. Daarvoor zijn deze indicatoren gerelateerd aan het landelijk gemiddelde. Daarbij worden indicatoren die rond het gemiddelde liggen $( \pm 10 \%)$ als gemiddelde beschouwd en indicatoren die meer dan de standaarddeviatie afwijken van het gemiddelde als 'erg hoog' of 'erg laag' getypeerd.

Uit een eerste blik op de indicatoren in bijlage IX blijkt dat deze sterk wisselend zijn per opleidingstype, maar minder sterk verschillen tussen de diverse RBA-gebieden. Hieruit mag geconcludeerd worden dat de regionale verschillen doorgaans minder belangrijk zijn dan de verschillen in de situatie op de arbeidsmarkt tussen de diverse opleidingstypen. Daarbij kan mogelijk een vertekening optreden, met name bij de twee onderscheiden algemene schooltypen

9. Indien het totaal aantal schoolverlaters voor een opleidingstype (de noemer van de indicator) in een bepaalde regio kleiner is dan 50 dan is de indicator niet berekend, omdat bij een dergelijke geringe aantallen erg snel een sterk vertekend beeld kan ontstaan. 
MAVO en HAVOIVWO, waarvan de fractie schoolverlaters erg klein is, omdat het merendeel van de gediplomeerden naar een andere (voltijds-)opleiding doorstroomt. Wanneer deze opleiding echter niet wordt afgemaakt, worden deze personen bij de arbeidsbureau's alsnog geregistreerd met hun MAVO- of HAVOIVWO-diploma. Hiervoor is een correctie aangebracht door de schoolverlaters zonder diploma van een bepaald opleidingstype op te tellen bij het opleidingstype van hun vooropleiding. Er wordt daarbij verondersteld dat de schoolverlaters zonder diploma procentueel dezelfde herkomst naar vooropleiding hebben als de gehele groep (scholieren en schoolverlaters) voor dat opleidingstype. Daarbij wordt gebruik gemaakt van de (landelijke) onderwijsmatrix van het C.B.S. Derhalve is deze correctie relatief gezien voor alle regio's hetzelfde. De werkelijke herkomst van schoolverlaters zonder diploma kan mogelijk echter landelijk zowel als regionaal van deze percentages afwijken. Bovendien kan er een afwijking ontstaan wanneer leerlingen niet in de eigen woonregio onderwijs volgen. Weliswaar wordt hiervoor gecorrigeerd in de RUVO-raming, maar er kan bijvoorbeeld mogelijk een afwijking onstaan wanneer een leerling na het volgen van onderwijs zich laat inschrijven in de regio waar de leerling onderwijs heeft gevolgd. Dit laatste kan ook verklaren waardoor voor een tweetal opleidingstypen in de RBA-regio Groningen het percentage werkloze schoolverlaters gerelateerd aan de totale uitstroom van schoolverlaters naar de arbeidsmarkt tot boven de $100 \%$ kan stijgen.

Er van uitgaande dat bovenstaande 'meetfout' in de meeste gevallen geen grote regiospecifieke component heeft, kan een indicator worden geconstrueerd van de relatieve werkloosheid voor de diverse opleidingstypen in de verschillende regio's. De werkloosheidsindicator wordt in dat geval gerelateerd aan het landelijke gemiddelde van de werkloosheidsindicator van het desbetreffende opleidingstype. Dit gemiddelde wordt daarvoor op 100 gesteld. De resultaten hiervan staan in bijlage $X$, schema $X .1$. Deze kengetallen vormen een maatstaf voor de regionale verschillen in de arbeidsmarktsituatie van een bepaald opleidingstype. Daarbij moet worden opgemerkt dat dit kengetal een zuiver relatieve maat is: een hoge waarde van de indicator betekent niet dat de werkloosheid van dit opleidingstype in deze regio hoog is in vergelijking met andere opleidingstypen. Het betekent alleen dat de werkloosheid relatief hoog is ten opzichte van het desbetreffende landelijk gemiddelde. In schema X.2 zijn deze kengetallen omgezet in een kwalitatieve typering van de relatieve verschillen in de regionale arbeidsmarktsituatie voor schoolverlaters per opleidingstype. Hiervoor zijn de kengetallen per opleidingstype gerelateerd aan het gemiddelde van het opleidingstype. Dit gebeurde op dezelfde wijze als bij de indicator, namelijk kengetallen die rond het gemiddelde liggen $( \pm 10 \%)$ worden als gemiddeld getypeerd en kengetallen die meer dan de standaarddeviatie afwijken van het gemiddelde worden als relatief 'erg hoog' of relatief 'erg laag' getypeerd (zie ook Wieling 1990). 


\section{CONCLUSIES}

In deze studie staat een arbeidsmarktindicator ten aanzien van de actuele situatie op de arbeidsmarkt voor schoolverlaters centraal. $\mathrm{Er}$ is gezocht naar een indicator voor de werkloosheid van schoolverlaters naar opleidingstype. De indicator geeft aan in hoeverre een werkzoekende schoolverlater van een bepaalde opleidingstype rekening moet houden met een bepaalde periode van werkloosheid. Daarbij is niet alleen de kans op een periode van werkloosheid van belang, maar ook de lengte van een dergelijke periode. Daarbij zijn twee verschillende methoden gebruikt om een dergelijke indicator te construeren.

Als eerste methode is een uitgebreid model gebruikt voor de werkloosheidsduren van een aantal opleidingstypen, waarbij de maatstaf kan worden gecorrigeerd voor leeftijd en geslacht. Een dergelijk model blijkt echter al snel te groot om te kunnen worden geschat. Bovendien wordt in een dergelijk model geen aandacht geschonken aan de kans om werkloos te worden na schoolverlaten. Als tweede methode worden de aantallen ingeschrevenen schoolverlaters gerelateerd aan het totaal aantal schoolverlaters. Deze meer eenvoudige indicator kan echter in bepaalde gevallen misleidend zijn. De indicator voor het laagste opleidingstype heeft bijvoorbeeld een redelijk gunstige waarde, terwijl uit de duuranalyse blijkt dat personen met dit opleidingstype, als ze werkloos zijn geworden, een erg lage hazard hebben, en dus een kleine kans om uit de werkloosheid te geraken.

Voor de constructie van regionale schoolverlatersgegevens is het noodzakelijk dat er een relevante regio-indeling wordt gekozen. Deze indeling moet niet te specifiek zijn maar er moeten op dat indelingsniveau wel voldoende betrouwbare gegevens zijn te verkrijgen. Een indeling die voor de hand ligt is de indeling naar 28 RBA-regio's. Hiervoor wordt dan ook in deze studie gekozen.

Vanuit het oogpunt van onze doelstelling is een eenvoudige werkloosheidsindicator met betrekking tot schoolverlaters naar de verschillende regio's waarschijnlijk het beste alternatief, omdat dan zowel de kans op een bepaalde werkloosheidsduur als de lengte van de betreffende duur invloed hebben op deze indicator. Bovendien is deze indicator relatief eenvoudig te berekenen en op basis van een kwalitatieve typering eenvoudig te interpreteren. 


\section{LITERATUUR}

Cox, D.R., en D. Oakes (1984), Analysis of Survival Data, Chapman and Hall, Londen.

Dekker, B., H. Detmar, P. van Hoesel (1986), Werkzoekendenbestanden van arbeidsbureaus. Verslag van een onderzoek naar bestandsvervuiling, Den Haag.

Dekker, R.J.P., A. de Grip, J.A.M. Heijke, Th.B.J. Beekman, H.M.M. Peeters (1990), De arbeidsmarktperspectieven van beroepsklassen en opleidingstypen in 1992: rapportage ISEE!, ROA, Maastricht.

Detmar, H., B. Dekker (1987), Het werkloosheidscijfer opnieuw beschouwd, Ministerie van Sociale Zaken, Stichting Research voor Beleid, Leiden.

Grip, A. de, J.A.M. Heijke (1988), Arbeidsmarktindicatoren: een inventarisatie, ROA-W-1988/1, Maastricht.

Kalbfleisch, J.D., R.L. Prentice (1980), The statistical analysis of failure time data, Wiley, New York.

Kerckhoffs, K., C. de Neubourg (1990), The duration of unemployment: determinants and political economy, Economische faculteit, Rijksuniversiteit Limburg, Maastricht.

Lancaster, T. (1979), Econometric models for the duration of unemployment, in: Econometrica, 47, pp. 939-979.

Meesters, M.J., J.M. Huson (1990), Schoolloopbanen en arbeidsmarktpositie, Research voor Beleid, Leiden.

Ministerie van Sociale Zaken en Werkgelegenheid (1990), Schoolverlatersbrief 1990, Den Haag.

Narendranathan, W., M.B. Stewart (1990), How does the income effect vary as unemployment spells lenghten ?: Some Semi-parametric evidence, paper EALE-conference, Lund.

Opstal, R. van, F. van de Pol (1990), The transition from school to work in 1979-1987 in the Netherlands, CBS, Voorburg.

Paridon, W.C.G.M. van (1987), De arbeidsmarktindicator, in: Management Berichten, jrg. 13, nr. 3, p. 42-46.

Vermeulen, M. (1990), Regionalisering Uitstroom Voortgezet Onderwijs (RUVO), TNO/INRO, Rijswijk/Delft.

Wieling, M.H., A. de Grip, E.J.T.A. Willems (1990), Een systematische kwalitatieve typering van arbeidsmarktinformatie, ROA-W-1990/8, Maastricht. 
$-19-$

\section{BIJLAGE I: OVERZICHT VAN DE OPLEIDINGSTYPEN}

$\mathrm{nr}$ benaming

1 Basisonderwijs

2 MAVO en onderbouw HAVO \& VWO

3 LBO Agrarisch

4 LBO Technisch

5 LBO Vervoer \& Haven

6 LBO Verpleging \& Ziekenverzorging

7 LBO Economisch \& Administratief

8 LBO Sociale Verzorging \& Horeca

9 LBO Beveiliging \& Bewaking

11 Bovenbouw HAVO \& VWO

12 MBO Leraar Sport \& Recreatie

$13 \mathrm{MBO}$ Agrarisch

14 MBO Technisch \& Laboratorium

15 MBO Vervoer \& Haven \& Telecom

$16 \mathrm{MBO}$ Verpleging

17 MBO Medisch Laboratorium

$18 \mathrm{MBO}$ Ziekenverzorging

19 MBO Economisch \& Administratief

20 MBO Bestuurlijk \& Recht \& Fiscaal

21 MBO Sociaal \& Cultureel

22 MBO Sociale Verzorging

23 MBO Horeca \& Kappersbedrijf

24 MBO Politie \& Brandweer \& Defensie

26 HBO Docentenopleidingen

27 HBO Tolk \& Vertaler

28 HBO Theologie

29 HBO Agrarisch

30 HBO Technisch Laboratorium

31 HBO Technisch

32 HBO Lucht- \& Zeevaart \& Verkeer

33 HBO Verpleging \& Fysiotherapie e.d.

34 HBO Medisch Laboratorium

35 HBO Diëtetiek \& Voedingsleer

36 HBO Economisch \& Administratief

37 HBO Technische Bedrijfskunde

38 HBO Bestuurlijk \& Recht \& Fiscaal

39 HBO Sociaal \& Cultureel

$40 \mathrm{HBO}$ Horeca

$41 \mathrm{HBO}$ Kunst

42 HBO Politie \& Brandweer \& Defensie

44 WO Docentenopleidingen

45 WO Letteren \& Geschiedenis e.d.

46 WO Theologie

47 WO Agrarisch

48 WO Wiskunde \& Natuurwetenschappen

49 WO Technisch

50 WO Dier- \& Genees- \& Tandheelkunde

51 WO Farmacie

52 WO Informatica, Economie,Bedrijfsk.

53 WO Econometrie \& Bedrijfskunde (ir)

54 WO Rechten \& Bestuurskunde
SOI-codes

000111201

301

321322323329

331336338339

341342343344349

351352354359

361362364366

381383384386

391392393394

401

406

421422423429

431436438439

441442443444449

451

452

454

453461462464

466

471

481484486

483

491492493494

506

511

516

521522523529

531

536538539

541542543544549

551

552

554

561

562

566

571

583

586

591592593594

606

611

616

621622623629

631

636638639

651

652

661

662

666 
$-20-$

55 WO Sociale Wetenschappen

671

56 WO Kunstwetenschappen

686

57 WO Land- \& Luchtmacht \& Marine

691692694 


\section{BIJLAGE II: SCHATTINGSRESULTATEN VAN MEESTERS EN HUSON (1990)}

Tabel II.1. Percentage schoolverlaters dat direct een baan vindt naar het hoogstbehaalde onderwijsdiploma en geslacht

\begin{tabular}{llll}
\hline & $\begin{array}{c}\text { mannen } \\
\%\end{array}$ & $\begin{array}{c}\text { vrouwen } \\
\%\end{array}$ & $\begin{array}{c}\text { totaal } \\
\%\end{array}$ \\
\hline & & & \\
geen diploma & 18.7 & 16.0 & 17.5 \\
lbo & 15.9 & 12.9 & 14.8 \\
mavo & 19.2 & 17.2 & 18.0 \\
havo & 16.4 & 15.0 & 15.4 \\
vwo & 12.9 & 14.2 & 13.7 \\
mbo & 31.6 & 16.5 & 19.8 \\
totaal & 17.9 & 15.3 & 14.6 \\
& & & \\
\hline
\end{tabular}

Tabel II.2. Gemiddelde duur van de startwerkloosheid naar het hoogstbehaalde onderwijsdiploma en geslacht, in maanden

\begin{tabular}{llll}
\hline & $\begin{array}{c}\text { mannen } \\
\%\end{array}$ & $\begin{array}{c}\text { vrouwen } \\
\%\end{array}$ & $\begin{array}{c}\text { totaal } \\
\%\end{array}$ \\
\hline & & & \\
geen diploma & 7.1 & 11.3 & 9.1 \\
lbo & 4.3 & 10.6 & 8.0 \\
mavo & 4.2 & 7.1 & 6.8 \\
havo & 6.0 & 5.6 & 5.7 \\
vwo & 8.8 & 7.7 & 8.0 \\
mbo & 3.3 & 5.5 & 5.1 \\
totaal & 6.4 & 8.4 & 7.5 \\
& & & \\
\hline
\end{tabular}




\section{BIJLAGE III: NIET-PARAMETRISCHE SCHATTING VAN DE SURVIVAL-CURVE}

Figuur III.1. Uitstroom fracties van het werkzoekendenbestand in de loop van de tijd ('survival verdeling'), mannen

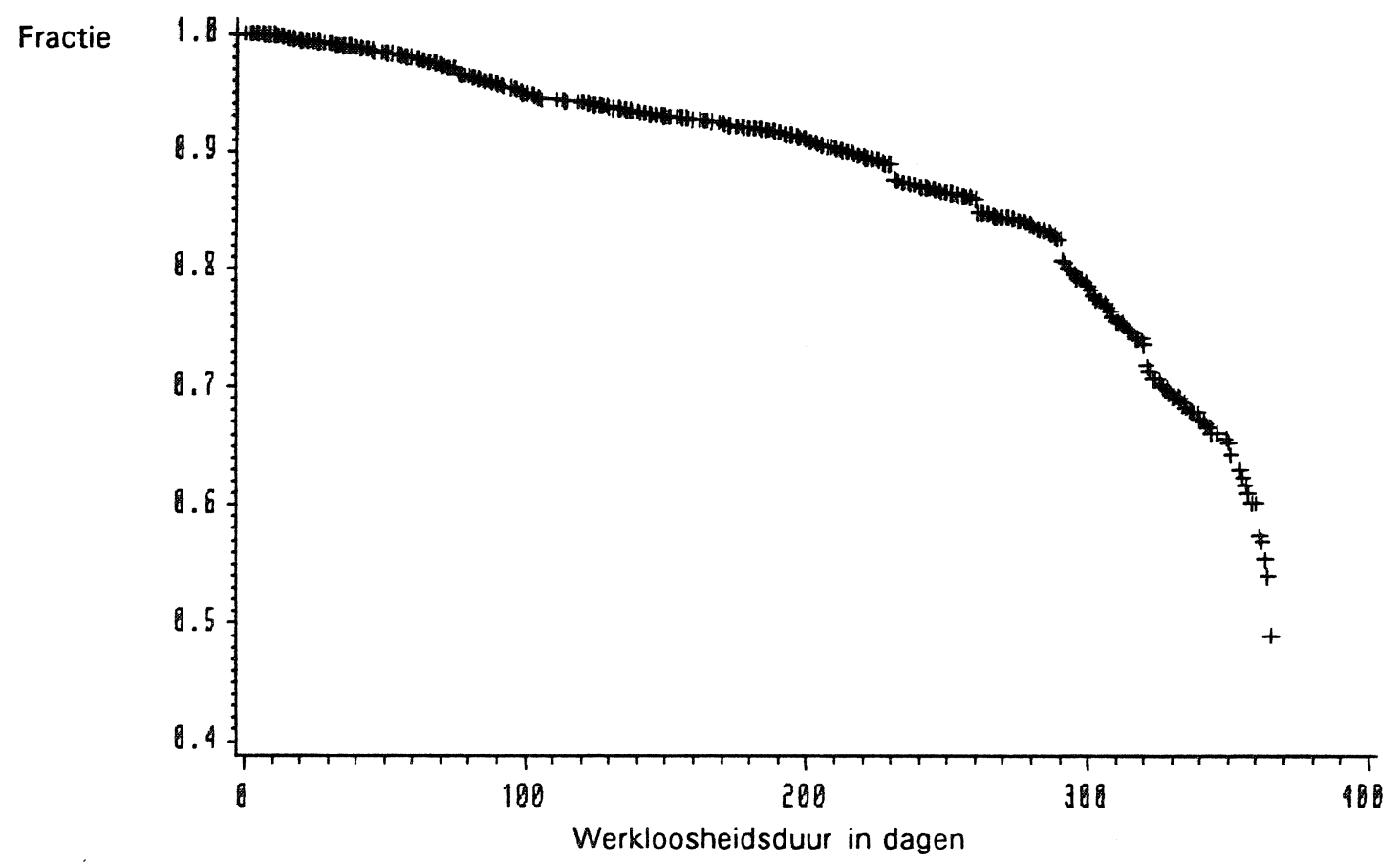

Bron: ROA

Figuur III.2. Uitstroom fracties van het werkzoekendenbestand in de loop van de tijd ('survival verdeling'), vrouwen

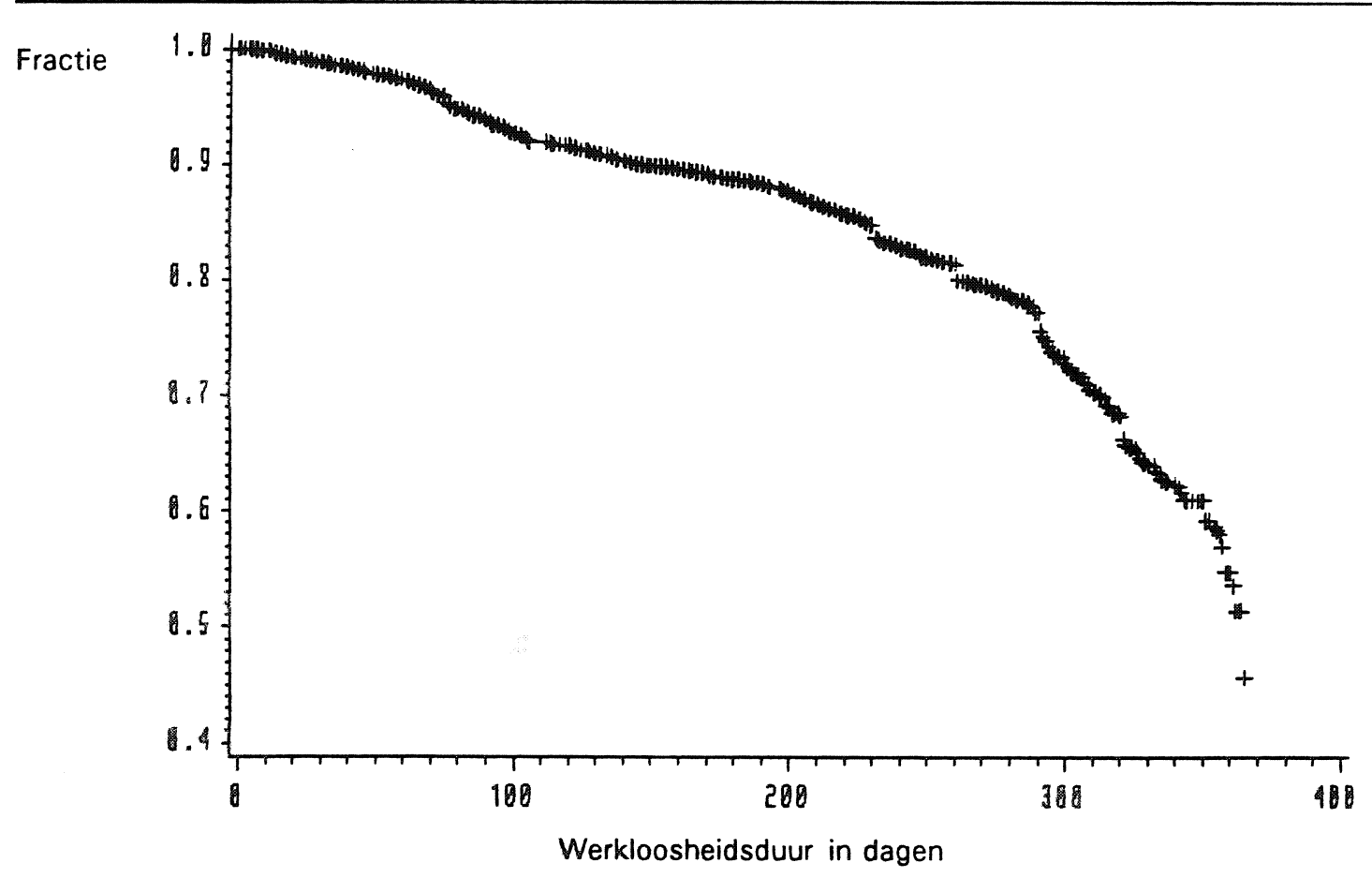


$-23-$

BIJLAGE IV: ARBEIDSMARKTINDICATOR VAN ROA-OPLEIDINGSCATEGORIEËN

\begin{tabular}{|c|c|c|c|c|c|}
\hline ROA & $\begin{array}{l}\text { Aantal } \\
\text { werkloze } \\
\text { schoolver- } \\
\text { laters }\end{array}$ & $\begin{array}{l}\text { Totaal } \\
\text { aantal } \\
\text { schoolver- } \\
\text { laters }\end{array}$ & $\begin{array}{l}\text { Werkloos- } \\
\text { heidspercen- } \\
\text { tage }\end{array}$ & $\begin{array}{l}\text { Gecorrigeerd } \\
\text { werkloosheids- } \\
\text { percentage }\end{array}$ & $\begin{array}{l}\text { Genormeerde } \\
\text { indicator }\end{array}$ \\
\hline 1 & 7357 & 28502 & 25.8 & 14.2 & 131 \\
\hline 3 & 542 & 2056 & 26.4 & 14.5 & 134 \\
\hline 4 & 2318 & 10358 & 22.4 & 12.3 & 114 \\
\hline 5 & 24 & 206 & 11.6 & 6.4 & 59 \\
\hline 7 & 2044 & 4214 & 48.5 & 26.7 & 247 \\
\hline 8 & 2882 & 4099 & 70.3 & 38.7 & 358 \\
\hline 11 & 7003 & 25272 & 27.7 & 15.2 & 141 \\
\hline 12 & 64 & 800 & 8.0 & 4.4 & 40 \\
\hline 13 & 339 & 7335 & 4.6 & 2.5 & 23 \\
\hline 14 & 1142 & 31455 & 3.6 & 2.0 & 18 \\
\hline 15 & 78 & 1256 & 6.2 & 3.4 & 31 \\
\hline 16 & 518 & 6584 & 7.9 & 4.3 & 40 \\
\hline 17 & 93 & 774 & 12.0 & 6.6 & 61 \\
\hline 18 & 30 & 2482 & 1.2 & 0.7 & 6 \\
\hline 19 & 2144 & 26505 & 8.1 & 4.5 & 41 \\
\hline 20 & 80 & 873 & 9.2 & 5.0 & 46 \\
\hline 21 & 824 & 4187 & 19.7 & 10.8 & 100 \\
\hline 22 & 1349 & 14110 & 9.6 & 5.3 & 48 \\
\hline 23 & 160 & 1858 & 8.6 & 4.7 & 43 \\
\hline 24 & 2 & 1290 & 0.2 & 0.1 & 0 \\
\hline 26 & 1477 & 7588 & 19.5 & 10.7 & 99 \\
\hline 27 & 114 & 125 & 91.1 & 50.1 & 464 \\
\hline 28 & 3 & 130 & 2.3 & 1.3 & 11 \\
\hline 29 & 213 & 1848 & 11.5 & 6.3 & 58 \\
\hline 30 & 83 & 929 & 8.9 & 4.9 & 45 \\
\hline 31 & 476 & 7166 & 6.6 & 3.7 & 33 \\
\hline 32 & 61 & 610 & 10.0 & 5.5 & 50 \\
\hline 33 & 931 & 5606 & 16.6 & 9.1 & 84 \\
\hline 34 & 12 & 498 & 2.4 & 1.3 & 12 \\
\hline 36 & 655 & 6654 & 9.8 & 5.4 & 50 \\
\hline 37 & 55 & 828 & 6.7 & 3.7 & 33 \\
\hline 38 & 112 & 644 & 17.4 & 9.6 & 88 \\
\hline 39 & 1314 & 5196 & 25.3 & 13.9 & 128 \\
\hline 40 & 57 & 417 & 13.7 & 7.5 & 69 \\
\hline 41 & 1074 & 1906 & 56.4 & 31.0 & 287 \\
\hline 42 & 1 & 250 & 0.4 & 0.2 & 2 \\
\hline 44 & 15 & 556 & 2.7 & 1.5 & 13 \\
\hline 45 & 1264 & 3602 & 35.1 & 19.3 & 178 \\
\hline 46 & 53 & 149 & 35.5 & 19.5 & 180 \\
\hline 47 & 318 & 847 & 37.5 & 20.7 & 191 \\
\hline 48 & 612 & 1614 & 37.9 & 20.9 & 193 \\
\hline 49 & 502 & 3404 & 14.8 & 8.1 & 75 \\
\hline 50 & 825 & 1879 & 43.9 & 24.2 & 223 \\
\hline 51 & 28 & 316 & 8.9 & 4.9 & 45 \\
\hline 52 & 382 & 3937 & 9.7 & 5.3 & 49 \\
\hline 53 & 51 & 736 & 6.9 & 3.8 & 35 \\
\hline 54 & 1012 & 4708 & 21.5 & 11.8 & 109 \\
\hline 55 & 1582 & 4551 & 34.8 & 19.1 & 177 \\
\hline 56 & 257 & 612 & 42.0 & 23.1 & 213 \\
\hline
\end{tabular}


$-24-$

\section{BIJLAGE V: OVERZICHT VAN DE DATASET EN SCHATTINGSRESULTATEN}

$\begin{array}{llr}\text { Aantal mannen } & : & 21946 \\ \text { Aantal vrouwen } & : & 26984 \\ \text { Aantal niet-nederlanders } & : & 3639 \\ \text { Gemiddelde werkloosheid } & : & 173.0 \mathrm{dgn} \\ \text { Gemiddelde leeftijd } & : & 22.8 \mathrm{jr}\end{array}$

Niet-gecensureerde waarnemingen : : 5706

Gecensureerde waarnemingen : $\quad 42524$

Observaties met ontbrekende waarden : $\quad 700$

Log Likelihood voor de GAMMA-verdeling:

$-17939.14622$

\begin{tabular}{|c|c|c|}
\hline Constante term & $5.139^{*}$ & 0.263 \\
\hline Leeftijd & $0.116^{*}$ & 0.014 \\
\hline Leeftijd ${ }^{2}$ & $-0.0016^{*}$ & 0.0003 \\
\hline Man & $-0.120^{*}$ & 0.019 \\
\hline Vrouw & 0 & 0 \\
\hline \multicolumn{3}{|c|}{ Opleidingsdummy } \\
\hline 1 & $0.512^{*}$ & 0.169 \\
\hline 2 & -0.314 & 0.163 \\
\hline 3 & -0.267 & 0.175 \\
\hline 4 & -0.257 & 0.166 \\
\hline 5 & -0.384 & 0.382 \\
\hline 7 & -0.183 & 0.166 \\
\hline 8 & -0.116 & 0.166 \\
\hline 10 & -0.363 & 0.228 \\
\hline 11 & -0.264 & 0.162 \\
\hline 12 & -0.281 & 0.262 \\
\hline 13 & $-0.372^{*}$ & 0.179 \\
\hline 14 & $-0.399^{*}$ & 0.167 \\
\hline 15 & $-0.570^{*}$ & 0.215 \\
\hline 16 & -0.290 & 0.175 \\
\hline 17 & $-0.663^{*}$ & 0.211 \\
\hline 18 & -0.559 & 0.280 \\
\hline 19 & $-0.295^{*}$ & 0.164 \\
\hline 20 & -0.420 & 0.214 \\
\hline 21 & -0.102 & 0.174 \\
\hline 22 & -0.156 & 0.168 \\
\hline 23 & $-0.593^{*}$ & 0.190 \\
\hline 25 & $-0.602^{*}$ & 0.207 \\
\hline 26 & -0.116 & 0.169 \\
\hline 27 & $-0.528^{*}$ & 0.218 \\
\hline 29 & $-0.689^{*}$ & 0.187 \\
\hline 30 & -0.312 & 0.260 \\
\hline 31 & $-0.813^{*}$ & 0.169 \\
\hline 32 & $-0.648^{*}$ & 0.228 \\
\hline 33 & $-0.397^{*}$ & 0.169 \\
\hline
\end{tabular}

10. Een sterretje bij de parameter geeft aan dat de variabele significant is op een niveau van 5 $\%$. 
$-25-$

$\begin{array}{lll}34 & -0.808^{*} & 0.343 \\ 36 & -0.738^{*} & 0.167 \\ 37 & -0.743^{*} & 0.233 \\ 38 & -0.363 & 0.235 \\ 39 & -0.335 & 0.167 \\ 40 & -1.019^{*} & 0.202 \\ 41 & -0.004^{*} & 0.173 \\ 43 & -0.568^{*} & 0.230 \\ 44 & -0.563 & 0.378 \\ 45 & -0.098 & 0.173 \\ 46 & -0.441 & 0.302 \\ 47 & -0.404^{*} & 0.190 \\ 48 & -0.295 & 0.178 \\ 49 & -0.855^{*} & 0.170 \\ 50 & -0.844^{*} & 0.166 \\ 51 & -1.124^{*} & 0.227 \\ 52 & -0.690^{*} & 0.178 \\ 53 & -0.958^{*} & 0.232 \\ 54 & -0.451^{*} & 0.169 \\ 55 & -0.194^{*} & 0.168 \\ 56 & 0 & 0 \\ \text { Dummy voor nationaliteit } & 0.141^{*} & 0.040 \\ \text { Gamma schaalparameter } & 0.128^{*} & 0.008 \\ \text { Gamma vormparameter } & 5.385^{*} & 0.343\end{array}$




\section{BIJLAGE VI: SCHATTINGSRESULTATEN VAN HET COX MODEL}

De bovenstaande coëfficiënten geven de invloed op de hazard weer; een negatief teken betekent derhalve een lagere hazard en dus c.p. een langere (verwachte) werkloosheidsduur.

Tabel VI.1. Schattingsresultaten van het Cox model van het laagste opleidingsniveau

$\begin{array}{lcc}\text { LOG LIKELIHOOD } & =-18665.9767 \\ \text { GLOBAL CHI-SOUARE }= & 598.51\end{array}$

GLOBAL CHI-SOUARE =

\begin{tabular}{|c|c|c|c|}
\hline VARIABELE & COEFFICIENT & $\begin{array}{l}\text { STANDAARD } \\
\text { FOUT }\end{array}$ & EXP(COEFF.) \\
\hline leeftijd & $-0.2469^{*}$ & 0.0306 & 0.7812 \\
\hline leeftijd ${ }^{2}$ & $0.0039^{*}$ & 0.0005 & 1.0039 \\
\hline nietnederlander & $-0.2571^{*}$ & 0.0786 & 0.7733 \\
\hline opl2 & $1.5285^{*}$ & 0.0771 & 4.6113 \\
\hline opl3 & $1.4770^{\circ}$ & 0.1270 & 4.3796 \\
\hline opl4 & $1.4271^{*}$ & 0.0863 & 4.1668 \\
\hline opl5 & $1.7032^{*}$ & 0.5817 & 5.4916 \\
\hline opl7 & $1.3134^{*}$ & 0.0913 & 3.7190 \\
\hline opl8 & $1.2334^{*}$ & 0.0880 & 3.4329 \\
\hline opl10 & $1.5866^{*}$ & 0.2755 & 4.8870 \\
\hline regio & $-0.0656^{*}$ & 0.0113 & 0.9365 \\
\hline geslacht & $0.2824^{*}$ & 0.0523 & 1.3264 \\
\hline
\end{tabular}

Tabel VI.2. Schattingsresultaten van het Cox model voor opleidingen op middelbaar niveau

LOG LIKELIHOOD $\quad=-16312.5791$

GLOBAL CHI-SOUARE $=164.71$

\section{VARIABELE}

\section{leeftijd}

leeftijd ${ }^{2}$

nietnederlander

opl12

opl13

opl14

opl15

opl16

opl17

opl18

opl19

opl20

opl21

opl22

opl23

opl25

regio

geslacht
STANDAARD

FOUT

EXP(COEFF.)

$\begin{array}{ccc}-0.1963^{*} & 0.0501 & 0.8218 \\ 0.0026^{*} & 0.0010 & 1.0026 \\ -0.2276 & 0.1430 & 0.7964 \\ -0.0459 & 0.3356 & 0.9551 \\ 0.1059 & 0.1381 & 1.1117 \\ 0.1978^{*} & 0.0837 & 1.2188 \\ 0.5540^{*} & 0.2525 & 1.7402 \\ -0.0326^{*} & 0.1181 & 0.9679 \\ 0.5892^{*} & 0.2615 & 1.8025 \\ 0.5024 & 0.4147 & 1.6527 \\ -0.0219^{*} & 0.0643 & 0.9784 \\ 0.2053 & 0.2453 & 1.2279 \\ -0.3416^{*} & 0.1124 & 0.7107 \\ -0.2599^{*} & 0.0859 & 0.7711 \\ 0.5609^{*} & 0.1834 & 1.7523 \\ 0.5192^{*} & 0.2387 & 1.6806 \\ -0.0451^{*} & 0.0117 & 0.9559 \\ 0.2513^{*} & 0.0527 & 1.2857\end{array}$


Tabel VI.3. Schattingsresultaten van het Cox model voor het hoogste opleidingsniveau

\begin{tabular}{|c|c|c|c|}
\hline VARIABELE & COEFFICIENT & $\begin{array}{l}\text { STANDAARD } \\
\text { FOUT }\end{array}$ & EXP(COEFF.) \\
\hline leeftijd & $-0.1798^{*}$ & 0.0573 & 0.8354 \\
\hline leeftijd ${ }^{2}$ & $0.0022^{*}$ & 0.0009 & 1.0022 \\
\hline nietnederlander & -0.1238 & 0.1861 & 0.8836 \\
\hline opl27 & $0.8183^{*}$ & 0.2585 & 2.2666 \\
\hline opl29 & $1.1274^{*}$ & 0.1888 & 3.0875 \\
\hline opl30 & 0.2301 & 0.3450 & 1.2588 \\
\hline opl31 & $1.3475^{*}$ & 0.1368 & 3.8479 \\
\hline opl32 & $0.9837^{*}$ & 0.3027 & 2.6742 \\
\hline opl33 & $0.4716^{*}$ & 0.1229 & 1.6026 \\
\hline opl34 & $1.1738^{\prime \prime}$ & 0.5851 & 3.2343 \\
\hline opl36 & $1.1764^{*}$ & 0.1232 & 3.2428 \\
\hline opl37 & $1.2469^{\circ}$ & 0.3148 & 3.4794 \\
\hline opl38 & 0.4878 & 0.2913 & 1.6288 \\
\hline opl39 & $0.3624^{*}$ & 0.1148 & 1.4368 \\
\hline opl40 & $1.7363^{*}$ & 0.2911 & 5.6761 \\
\hline opl41 & -0.1446 & 0.1349 & 0.8654 \\
\hline opl43 & $0.7759^{*}$ & 0.2905 & 2.1725 \\
\hline opl44 & 0.7912 & 0.5854 & 2.2060 \\
\hline opl45 & 0.1122 & 0.1356 & 1.1187 \\
\hline opl46 & 0.7138 & 0.4194 & 2.0416 \\
\hline opl47 & $0.5325^{*}$ & 0.1902 & 1.7032 \\
\hline opl48 & $0.4225^{*}$ & 0.1555 & 1.5257 \\
\hline opl49 & $1.4395^{*}$ & 0.1390 & 4.2185 \\
\hline opl50 & $1.3881^{*}$ & 0.1230 & 4.0072 \\
\hline opl51 & $1.9296^{*}$ & 0.3488 & 6.8868 \\
\hline opl52 & $1.1284^{*}$ & 0.1605 & 3.0907 \\
\hline opl53 & $1.7121^{*}$ & 0.3294 & 5.5404 \\
\hline opl54 & $0.6746^{*}$ & 0.1257 & 1.9633 \\
\hline opl55 & $0.2576^{*}$ & 0.1231 & 1.2938 \\
\hline opl56 & -0.0626 & 0.2588 & 0.9393 \\
\hline regio & -0.0176 & 0.0116 & 0.9825 \\
\hline geslacht & $0.1408^{*}$ & 0.0561 & 1.1512 \\
\hline
\end{tabular}




\title{
BIJLAGE VII: DE INDELING VAN DE RBA-REGIO'S
}

\author{
1 Groningen \\ 2 Friesland \\ 3 Drenthe \\ 4 Zwolle \\ 5 Twente \\ 6 Deventer/Zutphen \\ 7 Veluwe \\ 8 Arnhem/Oost-Gelderland \\ 9 Nijmegen/Rivierenland \\ 10 Flevoland \\ 11 Oost-Utrecht \\ 12 Midden- en West-Utrecht \\ 13 Het Gooi \\ $14 \mathrm{~N}-$ Holland-Noord \\ 15 Amsterdam/Zaanstreek \\ 16 Kennemer- en Amstelland \\ 17 Rijnstreek \\ 18 Den Haag/Delft \\ 19 Drechtsteden \\ 20 Rijnmond \\ 21 Zeeland \\ 22 West-Brabant \\ 23 Breda \\ 24 Tilburg/Waalwijk \\ 25 Den Bosch/Noordoost-Brabant \\ 26 Eindhoven/Helmond \\ 27 Midden- en Noord-Limburg \\ 28 Zuid-Limburg
}


$-29-$

\section{BIJLAGE VIII: LANDELIJK WERKLOOSHEIDSPERCENTAGE PER OPLEI- DINGSTYPE ${ }^{11}$}

2 MAVO en onderbouw HAVO, VWO

13,6

3 LAS e.a. Lager Agrarisch Onderwijs

5,0

4 LTS e.a. Lager Technisch Onderwijs

11,1

5 Lager Vervoer-, Havenonderwijs

4,1

7 LEAO, LMO, LHNO-Kantoor/Verkoop 14,6

8 Overig LHNO, LTS-Horeca e.d. 13,1

11 Bovenbouw HAVO VWO

13 Middelbaar Agrarisch Onderwijs $\quad 2,7$

14 Middelbaar Technisch Onderwijs 2,3

15 Middelbaar Vervoer-, Havenonderwijs 2,5

16 Middelbare Verpleegopleidingen $\quad 4,4$

17 Middelbaar Medisch Lab. Onderwijs $\quad 2,7$

19 MEAO (excl. Bestuurlijk), MMO e.d. 1,6

20 MEAO-Bestuurlijk e.d. $\quad 1,2$

21 Middelbare Sociaal-Culturele Opleidingen 13,2

11. Werkloosheidspercentage per 15-4'90 volgens Dekker cs. (1990). 


\section{BIJLAGE IX: DE WERKLOOSHEIDSINDICATOR NAAR OPLEIDINGSTYPE PER RBA-REGIO, APRIL $1990^{12}$}

Schema IX.1. Werkloosheidspercentage schoolverlaters naar opleidingstype per RBA-regio, april 1990

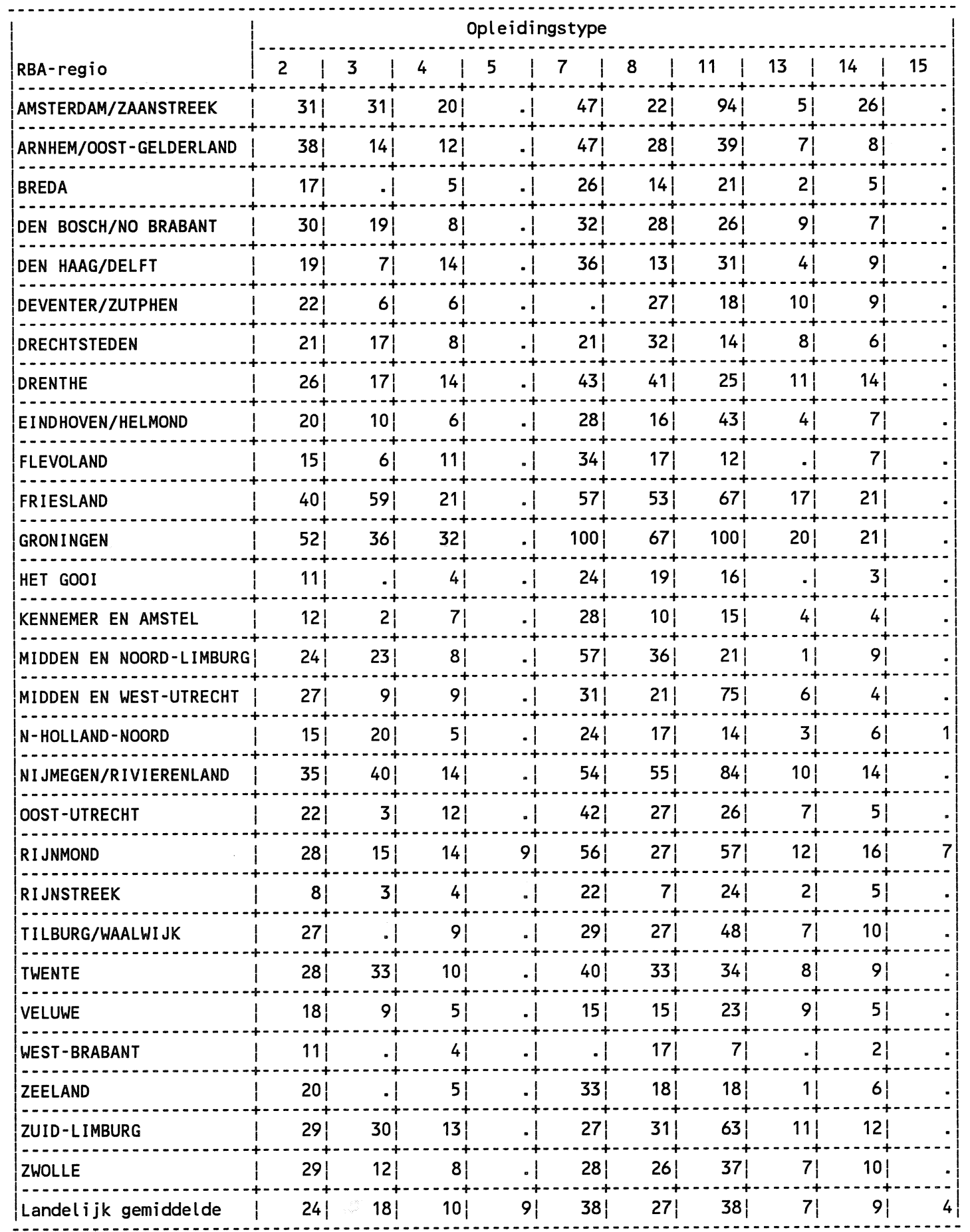

12. Voor twee opleidingstypen in Groningen (7 en 11) is de indicator op 100 afgekapt (zie de opmerking in de tekst). 


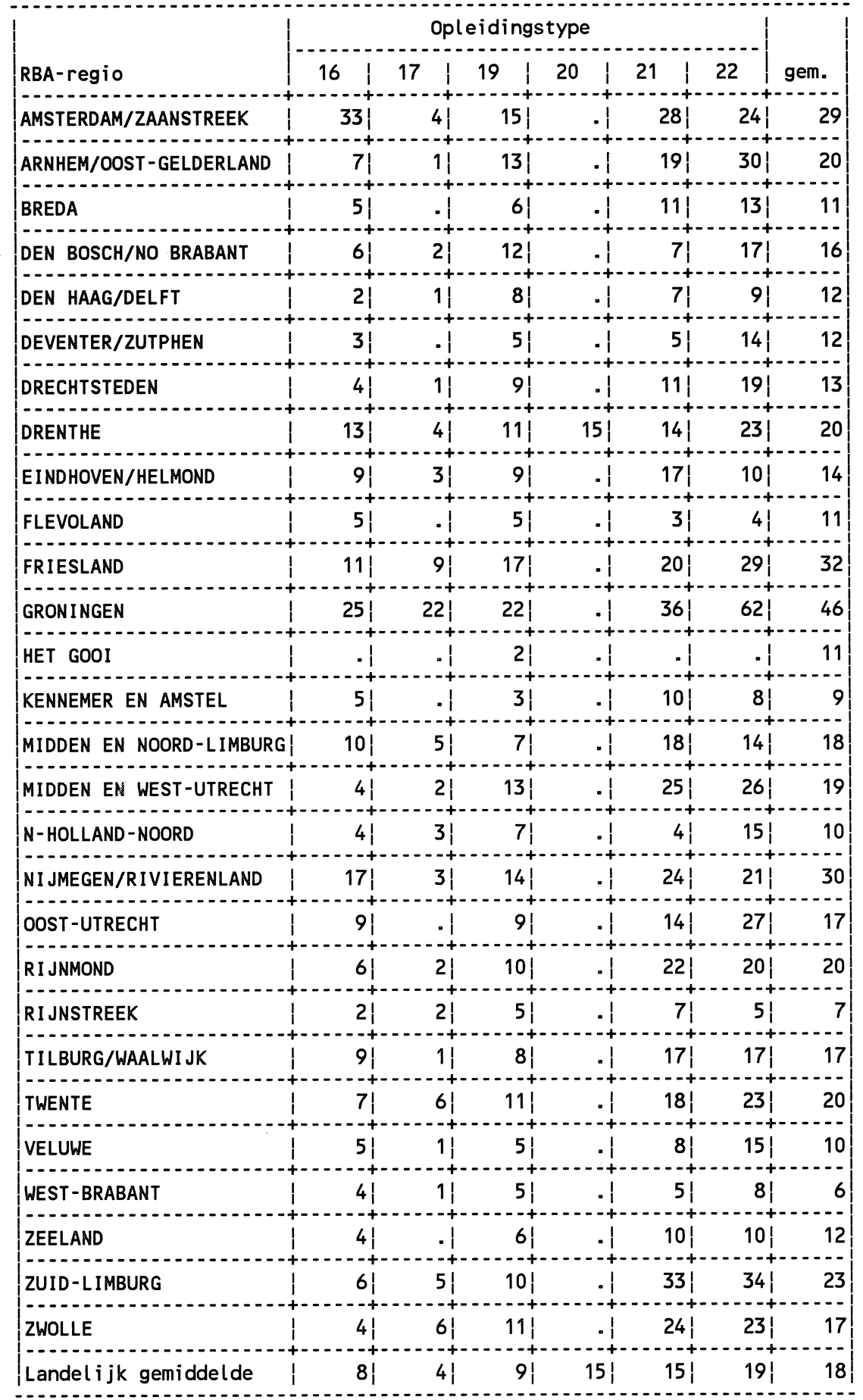


De werkloosheidsindicator naar opleidingstype per RBA-regio, april 1990 (weergegeven als kwalitatieve typering ten opzichte van het landelijk gemiddelde)

Schema IX.2. Kwalitatieve typering van de actuele arbeidsmarktsituatie van schoolverlaters naar opleidingstype per RBA-regio, april 1990

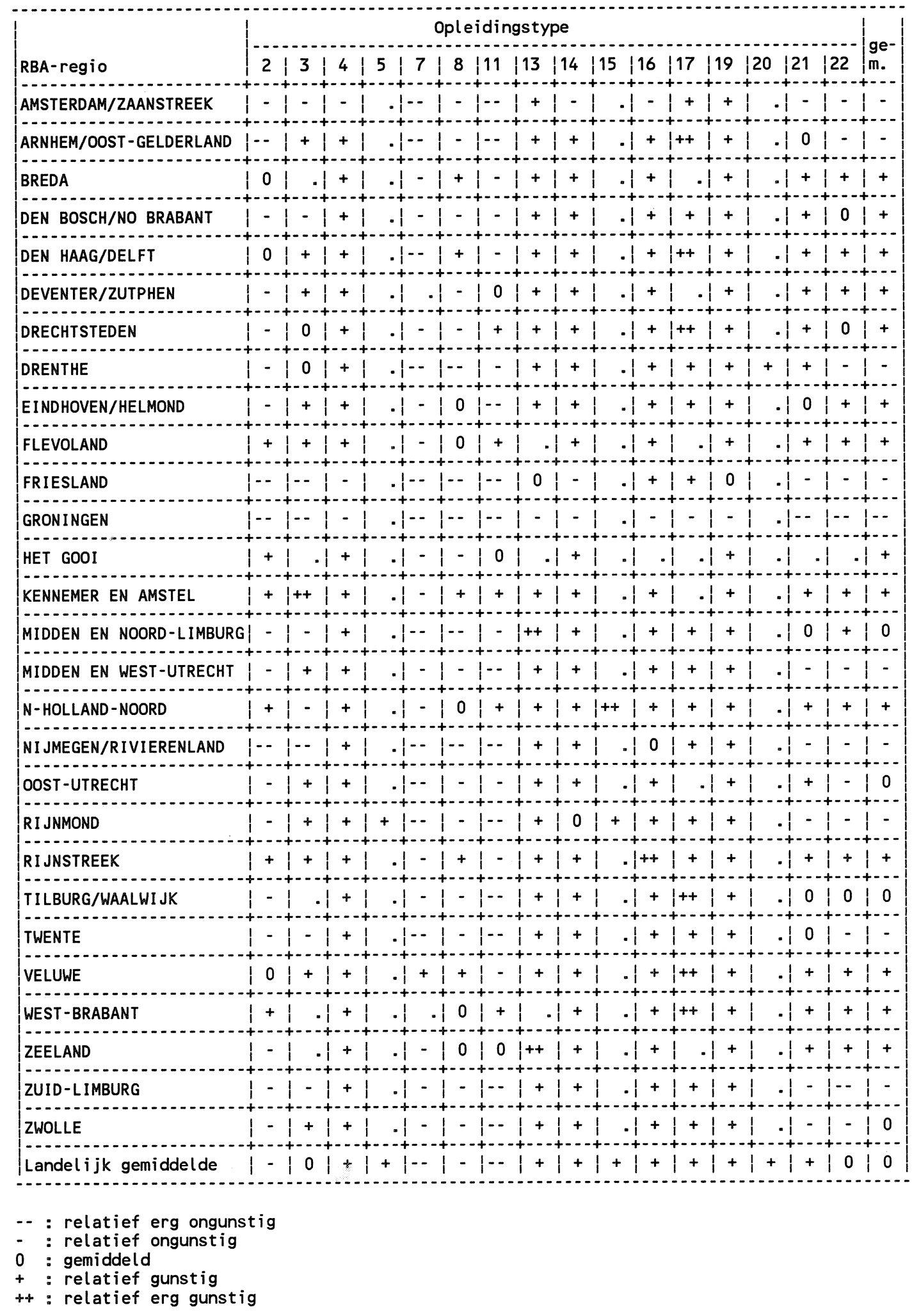




\section{BIJLAGE X: KENGETALLEN NAAR OPLEIDINGSTYPE PER RBA-REGIO, APRIL 1990}

Schema X.1. Kengetallen relatieve werkloosheid schoolverlaters naar opleidingstype per RBAregio, april 1990

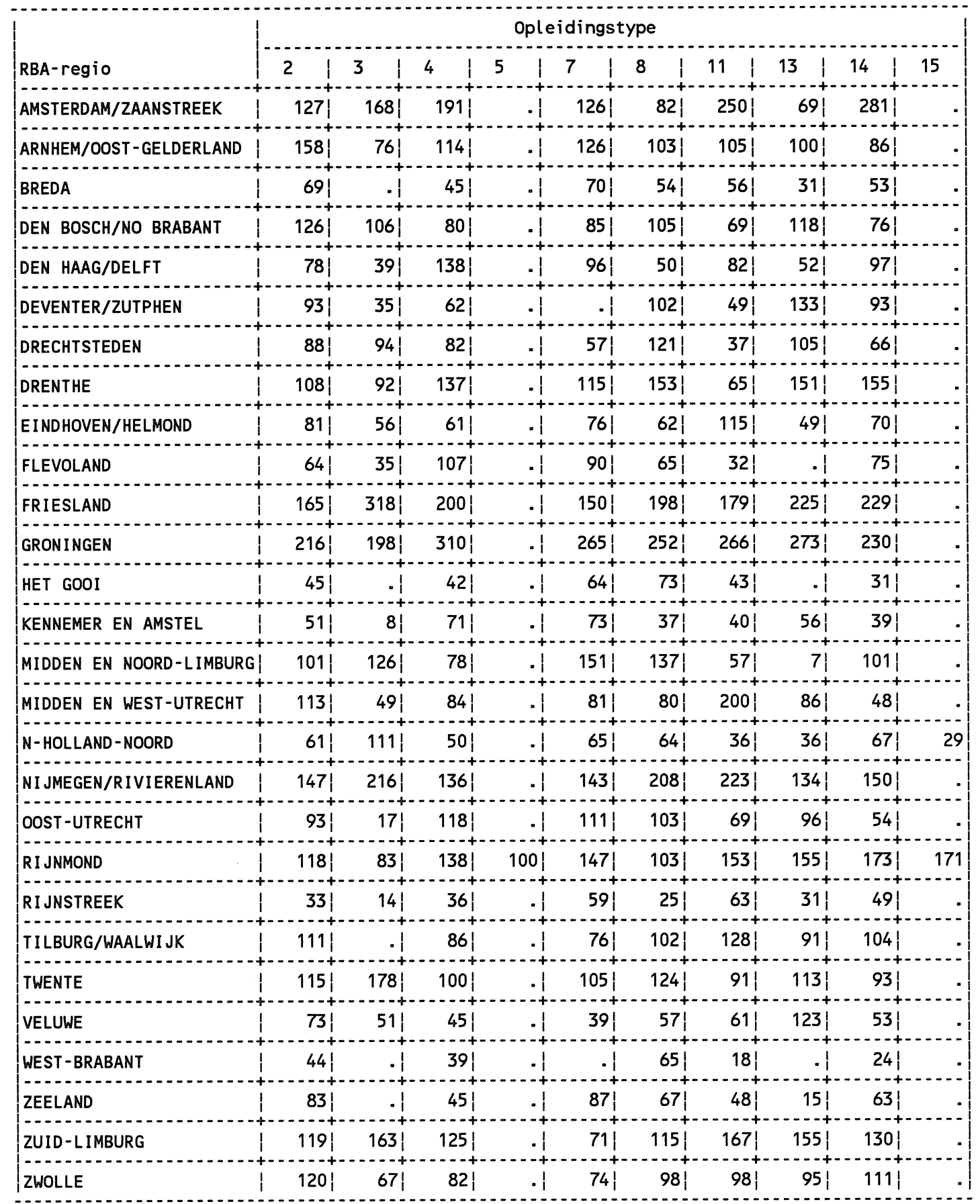




\begin{tabular}{|c|c|c|c|c|c|c|}
\hline \multirow[b]{2}{*}{ RBA-regio } & \multicolumn{5}{|c|}{ Opleidingstype } & \multirow[b]{2}{*}{ gem. } \\
\hline & 161 & 17 & 19 & 211 & 22 & \\
\hline AMSTERDAM/ZAANSTREEK & 405 & $102 \mid$ & 164 & 179 & $124 i$ & 174 \\
\hline ARNHEM/OOST-GELDERLAND & 891 & $19 \mid$ & 142 & 124 & $154 \mid$ & 107 \\
\hline BREDA & 58 & .1 & $66 \mid$ & 72 & 691 & 58 \\
\hline DEN BOSCH/NO BRABANT & 721 & $49 \mid$ & 134 & 47 & 901 & 89 \\
\hline DEN HAAG/DELFT & 25 & $29 \mid$ & 88 & 481 & 46 & 67 \\
\hline DEVENTER/ZUTPHEN & 42 & .1 & 58 & 35 & 701 & 70 \\
\hline DRECHTSTEDEN & 47 & 28 & 98 & 691 & 971 & 76 \\
\hline DRENTHE & 166 & 108 & 121 & 911 & 121 & 120 \\
\hline EINDHOVEN/HELMOND & $111 \mid$ & 84 & 94 & $111 \mid$ & $51 !$ & 78 \\
\hline FLEVOLAND & 601 & .1 & 54 & 201 & 23 & 57 \\
\hline FRIESLAND & $137 \mid$ & 219 & 179 & 127 & 152 & 191 \\
\hline GRONINGEN & 312 & 536 & 239 & 233 & 321 & 281 \\
\hline HET GOOI & .1 & .1 & 23 & .1 & .1 & 46 \\
\hline KENNEMER EN AMSTEL & 59 & .1 & 36 & 621 & 44 & 48 \\
\hline MIDDEN EN NOORD-LIME & 123 & 114 & 78 & 115 & 74 & 97 \\
\hline MIDDEN EN WEST-UTRECHT & 441 & 611 & $137 \mid$ & 162 & 136 & 99 \\
\hline N-HOLLAND-NOORD & 491 & 74 & 701 & 251 & 76 & 58 \\
\hline NI JMEGEN/R I VI IERENLAND & 209 & 701 & 146 & 156 & 110 & 157 \\
\hline OOST-UTRECHT & 117 & .1 & 101 & 89 & 142 & 92 \\
\hline RI JNMOND & 761 & 501 & 108 & 141 & 103 & 121 \\
\hline RI JNSTREEK & 191 & 45 & 53 & 48 & 27 & 39 \\
\hline TILBURG/WAALWI JK & 106 & 28 & 91 & 110 & $88 !$ & 93 \\
\hline TWENTE & $89 !$ & 145 & 123 & 114 & 118 & 116 \\
\hline VELUWE & 58 & 28 & 49 & 51 & 78 & 59 \\
\hline WEST-BRABANT & 47 & 35 & 56 & 36 & 401 & 40 \\
\hline ZEELAND & 52 & .1 & 591 & 631 & 501 & 57 \\
\hline ZUID-LIMBURG & 76 & $133 \mid$ & $112 \mid$ & $214 \mid$ & 178 & 135 \\
\hline ZWOLLE & 521 & 1441 & $120 \mid$ & $.157 \mid$ & $119 \mid$ & 103 \\
\hline
\end{tabular}


Schema X.2. Kwalitatieve typering van relatieve verschillen in de regionale arbeidsmarktsituatie van schoolverlaters per opleidingsniveau, april 1990

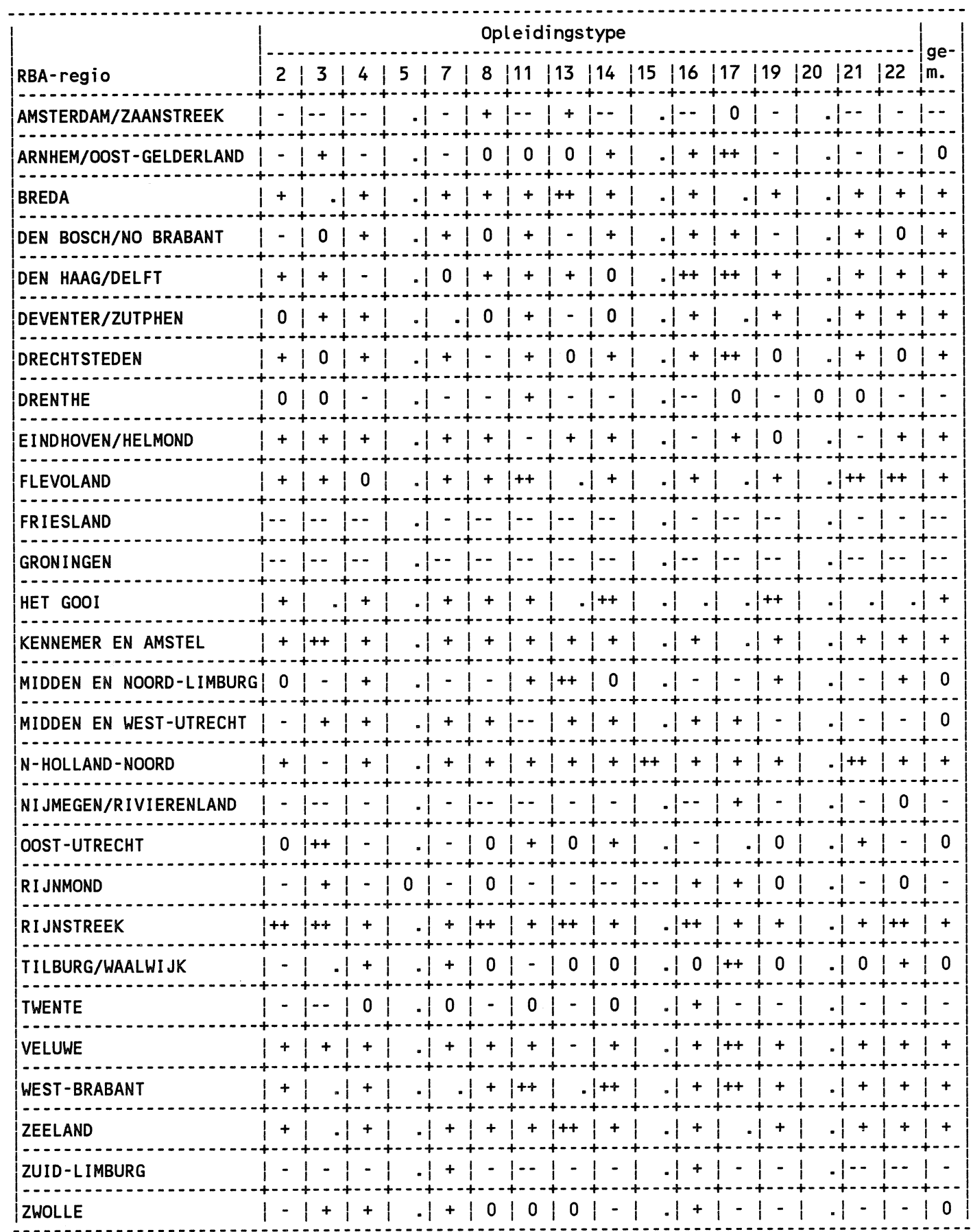

\footnotetext{
-. : relatief erg ongunstig

- : relatief ongunstig

0 : gemiddeld

+ : relatief gunstig

++ : relatief erg gunstig
} 


\section{BIJLAGE III: NIET-PARAMETRISCHE SCHATTING VAN DE SURVIVAL-CURVE}

Figuur III.1. Uitstroom fracties van het werkzoekendenbestand in de loop van de tijd ('survival verdeling'l, mannen

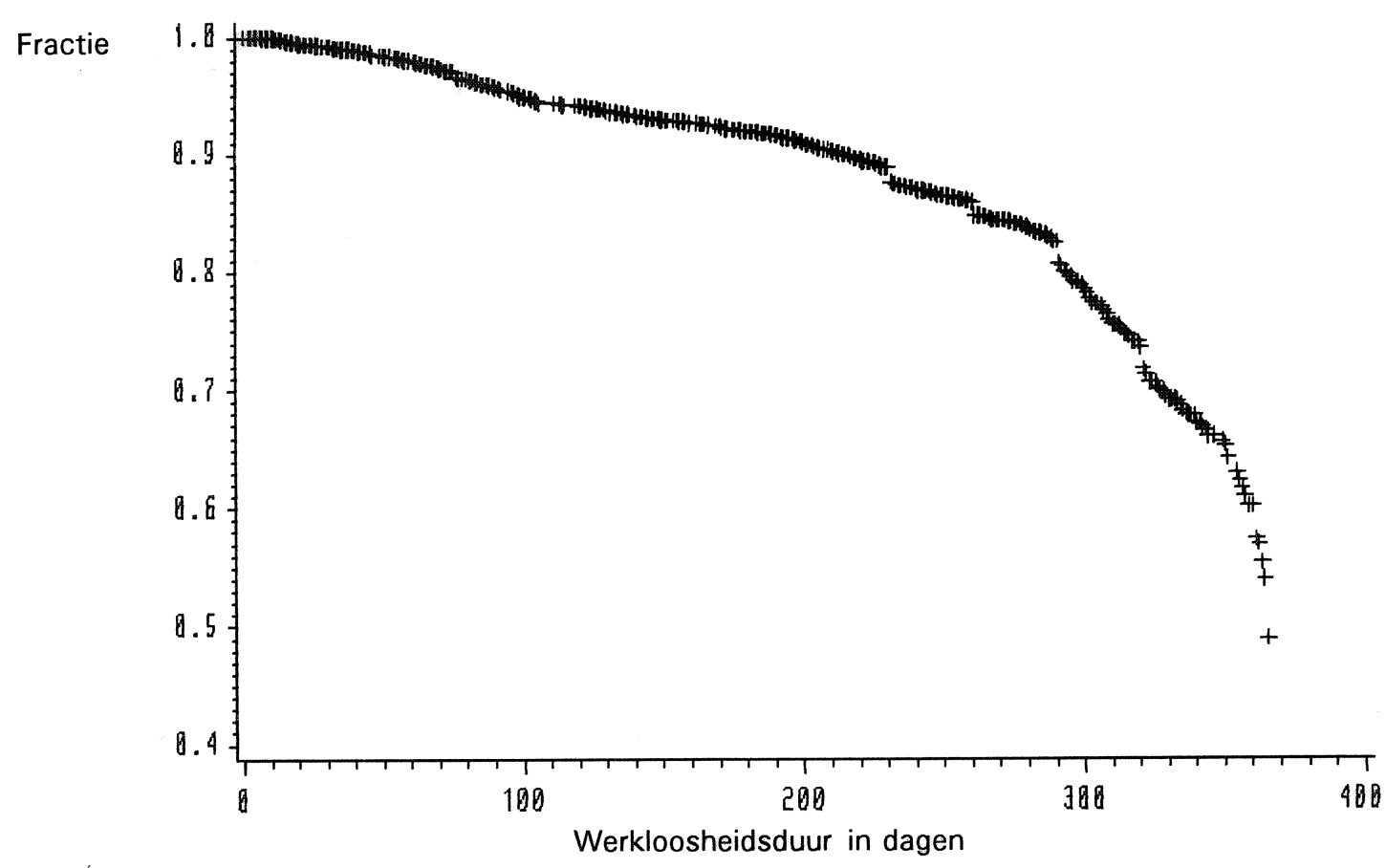

Bron: ROA

Figuur III.2. Uitstroom fracties van het werkzoekendenbestand in de loop van de tijd l'survival verdeling'), vrouwen

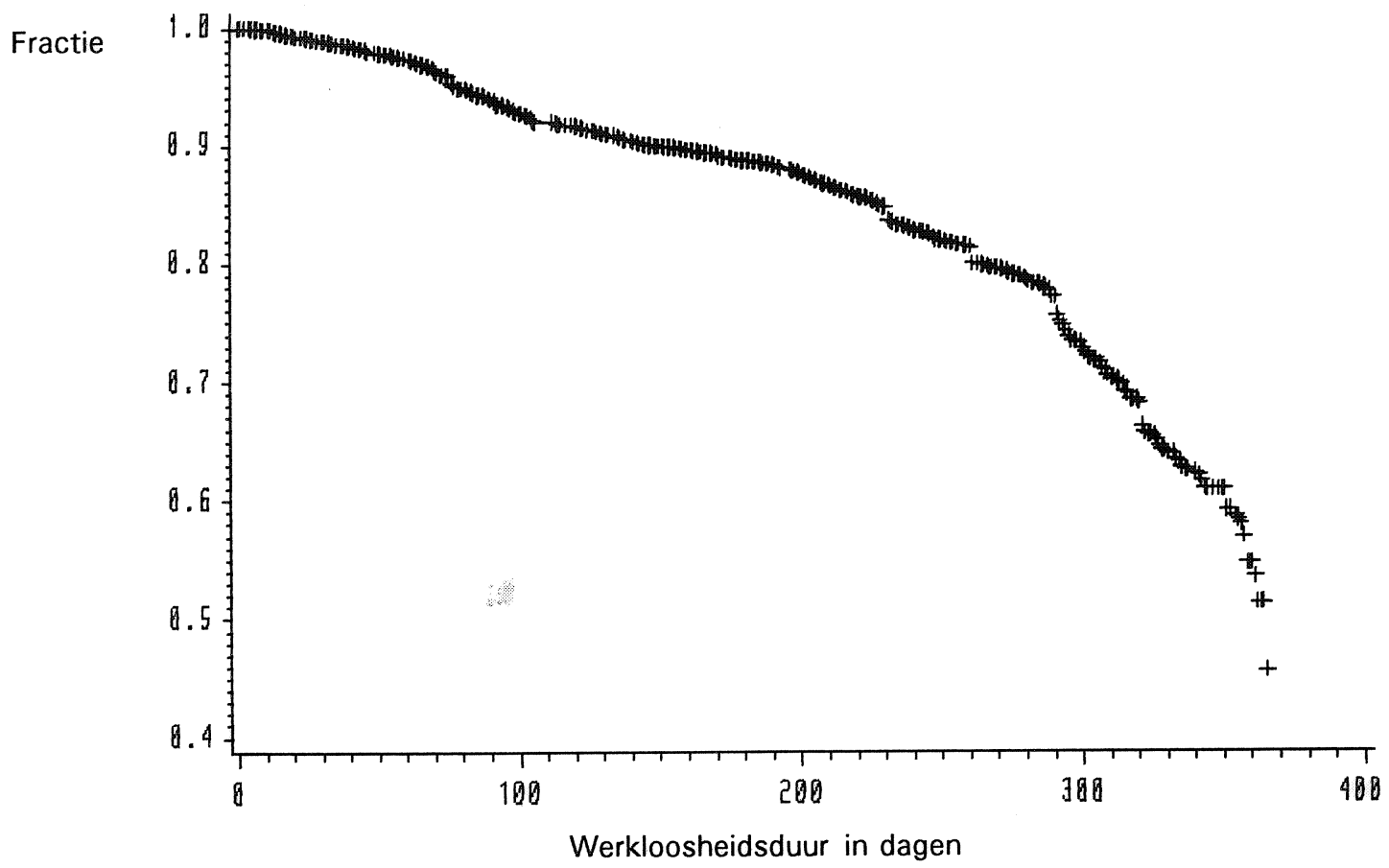




$$
\exists
$$




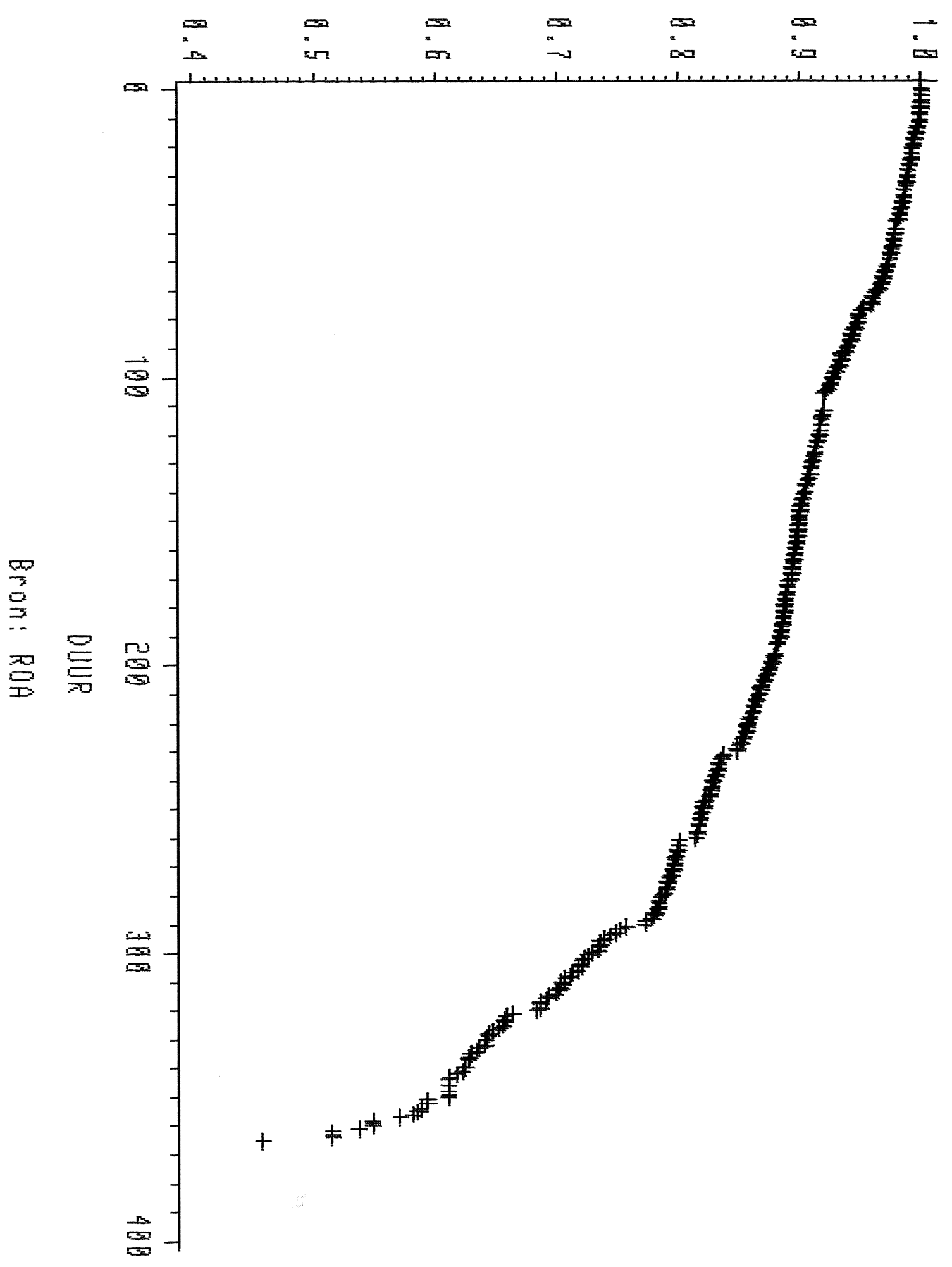

